\title{
Gold Compounds as Anticancer Agents: Chemistry, Cellular Pharmacology, and Preclinical Studies
}

\author{
Stefania Nobili, ${ }^{1}$ Enrico Mini, ${ }^{1}$ Ida Landini, ${ }^{1}$ Cbiara Gabbiani, ${ }^{2}$ \\ Angela Casini, ${ }^{3}$ and Luigi Messori ${ }^{2}$ \\ ${ }^{1}$ Department of Preclinical and Clinical Pharmacology, University of Florence, viale Pieraccini 6, \\ 50139 Florence, Italy \\ ${ }^{2}$ Department of Chemistry, University of Florence, via della Lastruccia 3, 50019 Sesto Fiorentino (Florence), Italy \\ ${ }^{3}$ Institut des Sciences et Ingénierie Chimiques, Ecole Polytechnique Fédérale de Lausanne (EPFL), \\ Lausanne, Switzerland
}

Published online 24 July 2009 in Wiley InterScience (www.interscience.wiley.com).

DOI 10.1002/med.20168

\begin{abstract}
Gold compounds are a class of metallodrugs with great potential for cancer treatment. During the last two decades, a large variety of gold(I) and gold(III) compounds are reported to possess relevant antiproliferative properties in vitro against selected human tumor cell lines, qualifying themselves as excellent candidates for further pharmacological evaluation. The unique chemical properties of the gold center confer very interesting and innovative pharmacological profiles to gold-based metallodrugs. The primary goal of this review is to define the state of the art of preclinical studies on anticancer gold compounds, carried out either in vitro or in vivo. The available investigations of anticancer gold compounds are analyzed in detail, and particular attention is devoted to underlying molecular mechanisms. Notably, a few biophysical studies reveal that the interactions of cytotoxic gold compounds with DNA are generally far weaker than those of platinum drugs, implying the occurrence of a substantially different mode of action. A variety of alternative mechanisms were thus proposed, of which those involving either direct mitochondrial damage or proteasome inhibition or modulation of specific kinases are now highly credited. The overall perspectives on the development of gold compounds as effective anticancer drugs with an innovative mechanism of action are critically discussed on the basis of the available experimental evidence. @ 2009 Wiley Periodicals, Inc. Med Res Rev, 30, No. 3, 550-580, 2010
\end{abstract}

Key words: gold compounds; cancer; pharmacology; preclinical drug evaluation

Correspondence to: Enrico Mini, Department of Pharmacology, University of Florence, viale Pieraccini 6, 50139 Florence, Italy, E-mail: enrico.mini@unifi.it

Correspondence to: Luigi Messori, Department of Chemistry, University of Florence, via della Lastruccia, 3, 50019 Sesto Fiorentino (Florence), Italy, E-mail: luigi.messori@unifi.it 


\section{INTRODUCTION}

Gold compounds have a long and important tradition in medicine (also known as chrysotherapy), which dates back to the ancient Egyptians and especially flourished during the late Middle Age and the Renaissance. Gold compounds were widely used in early times of modern pharmacology, for the treatment of several diseases, especially as anti-infective and antitubercular agents. Despite extensive clinical experimentation carried out at that pioneering time, gold compounds have had limited medical application and are presently used only for the treatment of severe rheumatoid arthritis. ${ }^{1,2}$ This is probably the result of their relevant systemic toxicity (e.g. nephrotoxicity) and of the poor chemical stability of the tested compounds. However, we believe that the unique chemistry of the gold center is not yet fully appreciated and may be further used for different and more relevant pharmacological purposes, especially in the field of anticancer medicine.

Following the clinical use of cisplatin, one of the first metal complexes to be extensively employed for cancer treatment, ${ }^{3}$ there have been several attempts to prepare and evaluate new gold compounds - either gold(III) or gold(I) - as experimental antitumor agents with particular focus on gold phosphine complexes. ${ }^{4,5}$ Some of these compounds showed very pronounced and encouraging antitumor actions in vitro and were the object of great attention; however, they were rapidly abandoned due to the occurrence of severe toxicity and to the generally lower in vivo efficacy (in comparison with the in vitro effects). In recent years, many new gold compounds - in most cases gold(III) compounds-have been synthesized and characterized, which show greater chemical stability and a far better toxicological profile, which undoubtedly warrant additional pharmacological testing. The structural and solution chemistry of these novel gold compounds and their reactivity with a variety of possible biomolecular targets are the object of recent reviews and will be briefly outlined here. $^{6,7}$

The main scope of this article is to describe the most representative pharmacological studies on anticancer gold compounds. Although this topic is essential to the development of new drug-lead compounds as well as for the planning of future clinical studies, it has been very marginally considered in the previous literature and deserves, in our opinion, far greater attention.

\section{CHEMISTRY OF GOLD COMPOUNDS}

\section{A. General Remarks}

The chemistry of gold contains some unique aspects that are most likely the consequence of important unique electronic properties of the gold center. For instance, gold has a great propensity to form strong gold-gold bonds (the so-called "aurophilic interactions"). ${ }^{8}$ A rich redox chemistry is associated with the three main oxidation states of gold. In turn, redox changes are strictly linked to changes in the coordination sphere with a frequent switch from square planar gold(III) complexes to linear dicoordinated gold(I) complexes. ${ }^{2}$ All these aspects may be exploited to build up a variety of gold-based pharmacologically active compounds.

The most important oxidation states for gold are the following: $\mathrm{Au}(0), \mathrm{Au}(\mathrm{I})$, and $\mathrm{Au}(\mathrm{III})$. The elemental forms of gold, principally metallic and colloidal gold, are stable; however, in the presence of relatively strong ligands, elemental gold can undergo rather facile oxidation. The chemistry of gold complexes in the oxidation states +1 and +3 has been investigated in depth as well as their behavior in solution and reactivity with 
biomolecules. ${ }^{2,9,10}$ A relatively easy interchange between the oxidation states +1 and +3 even under physiological conditions is possible. ${ }^{4}$ This specific property may be pharmacologically relevant. There are some excellent books and reviews ${ }^{2,11}$ for readers wanting a more extensive description of gold chemistry.

\section{B. Gold(I) Compounds}

Gold(I) has a $\mathrm{d}^{10}$ closed-shell configuration, which is the basis for three principal coordination environments: linear two-coordination, by far the most important, but also trigonal three-coordination and tetrahedral four-coordination.

Gold(I) is a soft cation with a preference for soft ligands. Thus, cyanide, thiolate, and soft halides (e.g. iodide) tend to form stable $\mathrm{AuX}_{2}^{-}$ions; on the other hand, phosphines, arsines, and other neutral ligands readily form a variety of cationic complexes of the $\mathrm{AuL}_{2}^{+}$ and $\mathrm{AuL}_{4}^{+}$type.

The most important gold(I) compounds for medicinal purposes are thiolate and phosphine complexes, which are most often dicoordinate gold(I) complexes. Some representative examples of medicinally relevant gold(I) compounds, notably, auranofin, aurothiomalate, aurothioglucose, and auro-bis(thiosulfate), are shown in Figure 1. Structural data are available for the reported compounds. ${ }^{1}$ Auranofin exists as a monomeric species, while the other compounds have been isolated in solid state in oligomeric forms. The aqueous solution chemistry of these compounds has been intensely investigated ${ }^{10,12}$ and indicates that thiolate ligands are usually more labile than phosphine ligands and undergo rapid aquation. The resulting cationic species usually show a strong reactivity with biomolecules. Analogously, phosphine ligands may undergo aquation but these reactions are generally far slower.

The electrochemical behavior of gold(I) drugs has also been investigated in detail. ${ }^{13,14}$ Auranofin can undergo reduction to colloidal gold, the process being irreversible. Cyclic voltammetry studies show sufficiently high reduction potentials for auranofin, myocrisin, and the parent compounds so that all these compounds may be easily and quickly reduced by glutathione and other thiols within the cellular environment.

\section{Gold(III) Compounds}

Gold(III) has a $\mathrm{d}^{8}$ closed-shell configuration, which originates metal complexes that are isoelectronic and isostructural to platinum(II) complexes; accordingly, the dominant coordination geometry for gold(III) complexes is square planar tetra-coordination. The bond lengths are shorter than the corresponding gold(I) bond lengths although differences are not

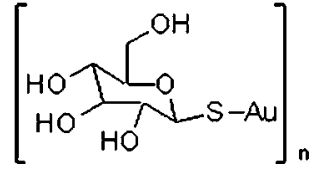

(a)<smiles>OC(CS[Ga])C[AsH]1CC[AsH]1</smiles>

(b)

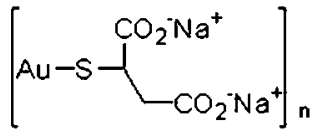

(c)

$$
N a_{3}\left[O_{3} S-S-A u-S-S O_{3}\right]
$$

(d)

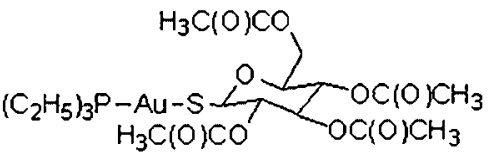

(e)

Figure 1. Schematic drawing of some gold(I) thiolates used in the treatment of rheumatoid arthritis: aurothioglucose (solganol) (a), aurothiopropanol sulfonate (allocrysin) (b), aurothiomalate (myochrysine) (c), auro-bis(thiosulfate) (sanochrysine) (d), and auranofin (ridaura) (e). 
very large. Five- and six-coordinate complexes are also found that typically exhibit elongated axial bond lengths perpendicular to the square plane and often involve ligand structures that constrain the axial donor atoms. The reactivity behavior of the gold(III) cation is borderline, showing a preference not only for soft ligands but also for nitrogen donors. The oxidation state +3 is strongly oxidizing unless the gold(III) cation is stabilized by an appropriate set of nitrogen or soft donors.

A vast array of gold(III) complexes showing rather variegated structural chemistry have been considered as potential anticancer $\operatorname{drugs}^{9}$ and several of them are discussed in this review. The gold(III) compounds of interest may be grouped into the four following classes: (i) classical mononuclear gold(III) complexes; (ii) gold(III) porphyrins; (iii) organogold(III) compounds; (iv) dinuclear gold(III) complexes.

\section{Classical Mononuclear Gold(III) Complexes}

The main compounds of this class are shown in Figure 2. They are square planar gold(III) compounds mostly with nitrogen or halide ligands: $\mathrm{AuCl}_{4}^{-},[\mathrm{Au}(\mathrm{dien}) \mathrm{Cl}] \mathrm{Cl}_{2}$ (Audien), $\left[\mathrm{Au}(\mathrm{en})_{2}\right] \mathrm{Cl}_{3}$ (Auen), [Au(cyclam) $]\left(\mathrm{ClO}_{4}\right)_{2} \mathrm{Cl}$ (Aucyclam), [Au(terpy)Cl] $\mathrm{Cl}_{2}$ (Auterpy), $\left[\mathrm{Au}(\right.$ phen $\left.) \mathrm{Cl}_{2}\right] \mathrm{Cl}$ (Auphen). ${ }^{15}$ Structural data are reported for all these compounds. As nitrogen ligands are stronger and less labile than chloride ligands, it follows that chloride ligands undergo far more facile aquation reactions that lead to complex activation. In turn, nitrogen ligands induce significant stabilization of the oxidation state +3 . The solution behavior of these compounds has been investigated. $\mathrm{AuCl}_{4}^{-}$is poorly stable in physiological $\mathrm{pH}$ due to rapid and progressive release of its chloride ligands; in turn, Aucyclam is very stable due to the equatorial donor set. In the other cases chloride release has been monitored affording cationic species with at least one reactive coordination position. Notably, other compounds belonging to this group are gold(III) dithiocarbamate complexes. The compounds containing $N, N$-dimethyldithiocarbamate and ethylsarcosinedithiocarbamate ligands, developed in Padua, have been intensely studied as possible anticancer agents (Fig. 3, compounds 5 and 6$)^{16}$

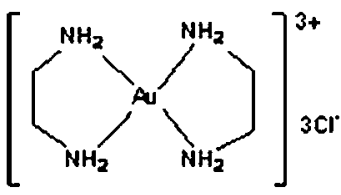

(1)

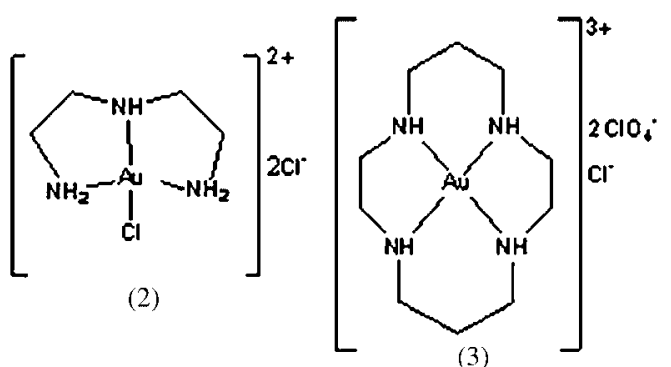

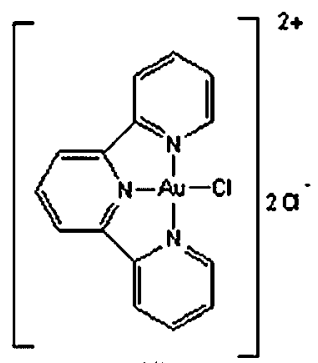

(4)

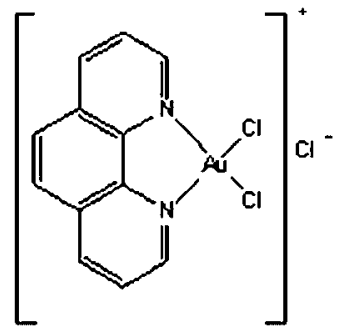

(5)

Figure 2. Schematic drawing of $\left[\mathrm{Au}\left(\mathrm{en}_{2}\right)\right] \mathrm{Cl}_{3}(\mathbf{1}),[\mathrm{Au}(\mathrm{dien}) \mathrm{Cl}] \mathrm{Cl}_{2}(\mathbf{2}),[\mathrm{Au}(\mathrm{cyclam})]\left(\mathrm{ClO}_{4}\right)_{2} \mathrm{Cl}(\mathbf{3}),[\mathrm{Au}(\mathrm{terpy}) \mathrm{Cl}] \mathrm{Cl}_{2}(\mathbf{4})$, and $\left[\mathrm{Au}(\right.$ phen $\left.) \mathrm{Cl}_{2}\right] \mathrm{Cl}(\mathbf{5})$. 

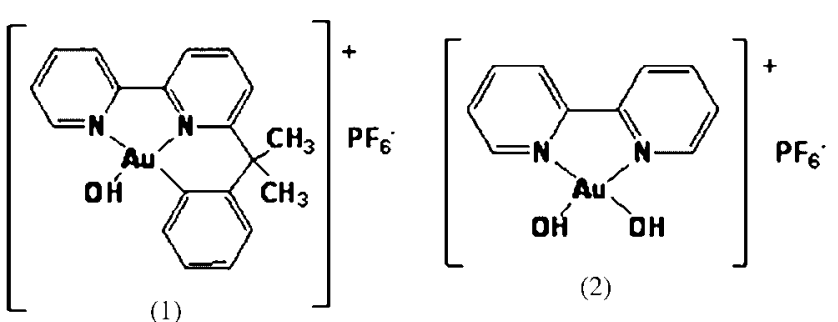

(2)

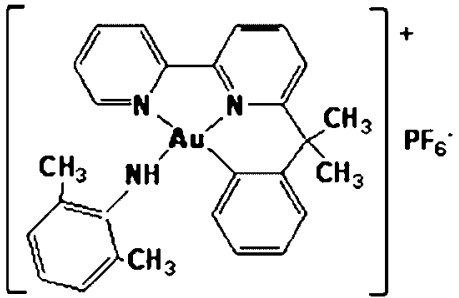

(3)

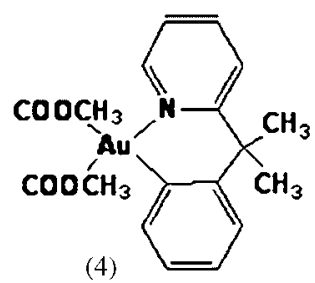

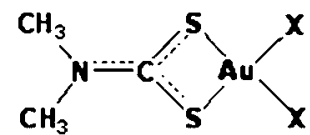

(5)

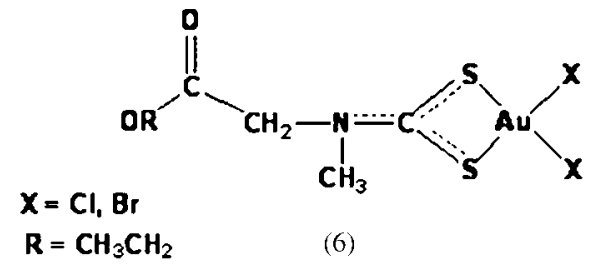

Figure 3. Schematic drawing of $\left[\mathrm{Au}\left(\mathrm{bipy}^{\mathrm{C}}-\mathrm{H}\right)(\mathrm{OH})\right]\left[\mathrm{PF}_{6}\right](\mathbf{1}),\left[\mathrm{Au}(\mathrm{bipy})(\mathrm{OH})_{2}\right]\left[\mathrm{PF}_{6}\right](\mathbf{2}),\left[\mathrm{Au}\left(\mathrm{bipy}^{\mathrm{dmb}}-\mathrm{H}\right)\left(2,6-\mathrm{xyllidine}^{-}-\mathrm{H}\right)\right]\left[\mathrm{PF}_{6}\right]$ (3), $\left[\mathrm{Au}\left(\mathrm{py}^{\mathrm{dmb}}-\mathrm{H}\right)(\mathrm{AcO})_{2}\right]$ (4) (where py ${ }^{\mathrm{dmb}}=2$-(1,1-dimethylbenzyl)-pyridine), and of the gold(III) dithiocarbamate complexes containing $\mathrm{N}, \mathrm{N}$-dimethyldithiocarbamate (5) and ethylsarcosinedithiocarbamate (6) ligands.

\section{Gold(III) Porphyrins}

The porphyrin ligand greatly stabilizes the gold(III) center and drastically reduces its redox reactivity and oxidizing character. ${ }^{17}$ Crystal structures have been reported. ${ }^{17}$ It is very unlikely that metalloporphyrin demetallation may occur with the release of the gold(III) ion. Similarly gold(III) reduction to gold(I) or elemental gold is very unlikely. This means that the biological activity of gold(III) porphyrins must be ascribed to the intact molecule. It has been hypothesized that the primary target for gold(III) porphyrins is DNA following intercalation; however, recent studies reveal that gold(III) porphyrins may greatly affect mitochondrial functions as well. ${ }^{18}$

\section{Organogold(III) Compounds}

Gold(III) compounds belonging to this class are characterized by the presence of at least one direct carbon-gold(III) bond; this latter feature is very important for the stabilization of gold oxidation state +3 . Examples of organogold(III) compounds relevant to this review are shown in Figure 3. Organogold(III) compounds are generally stable under physiological conditions and have a scarce tendency to be reduced to gold(I). They are significantly cytotoxic to human tumor cell lines. ${ }^{19,20}$

\section{Dinuclear Gold(III) Complexes}

A series of structurally related oxo-bridged dinuclear gold(III) compounds, $\left[\mathrm{Au}_{2}(\mu-\mathrm{O})_{2}\right.$ $\left.\left(N^{\wedge} N\right)_{2}\right]\left(\mathrm{PF}_{6}\right)_{2}$, where $N^{\wedge} N$ is 2,2'-bipyridine or a substituted 2,2'-bipyridine, have recently been shown to exhibit appreciable stability under physiological-like conditions and to manifest important antiproliferative effects toward selected human tumor cell lines (Fig. 4).

All these compounds contain a common structural motif consisting of an $\mathrm{Au}_{2} \mathrm{O}_{2}$ "diamond core" linked to two bipyridine ligands in a roughly planar arrangement. Interestingly, the introduction of different kinds of alkyl or aryl substituents on the 6 (and $6^{\prime}$ ) position(s) of the bipyridine ligand leads to small structural changes that nonetheless greatly affect the reactivity of the metal centers. The 6,6'-dimethyl-2,2'-bipyridine derivative, which shows the largest structural deviation compared with the model compound $\left[\mathrm{Au}_{2}(\mu-\mathrm{O})_{2}(\mathrm{bipy})_{2}\right]\left(\mathrm{PF}_{6}\right)_{2}$, also has the highest oxidizing power, the least thermal stability, and the greatest cytotoxic 

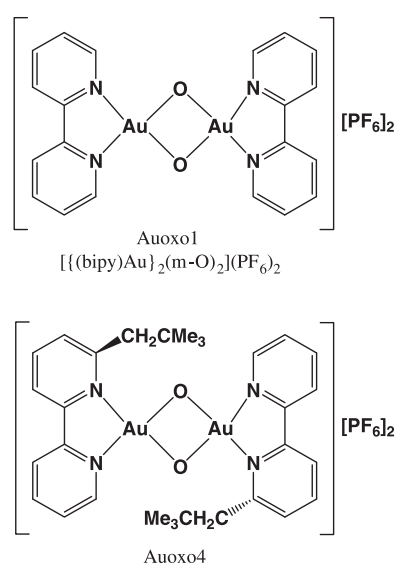

$\left[\left\{\left(6-\mathrm{CH}_{2} \mathrm{CMe}_{3} \text { bipy }\right) \mathrm{Au}\right\}_{2}(\mathrm{~m}-\mathrm{O})_{2}\right]\left(\mathrm{PF}_{6}\right)_{2}$

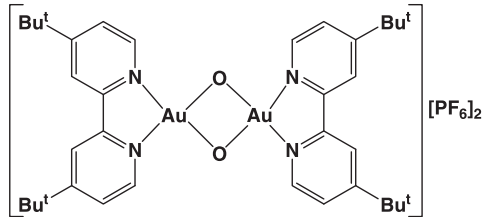

Auoxo2
$\left[\left\{4,4^{\prime}-\mathrm{Bu}_{2}^{\mathrm{t}}(\right.\right.$ bipy $\left.) \mathrm{Au}_{2}(\mathrm{~m}-\mathrm{O})_{2}\right]\left(\mathrm{PF}_{6}\right)_{2}$

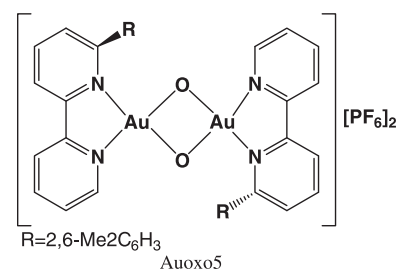

$\left[\{(6-\mathrm{Rbipy}) \mathrm{Au}\}_{2}(\mathrm{~m}-\mathrm{O})_{2}\right]\left(\mathrm{PF}_{6}\right)_{2}$

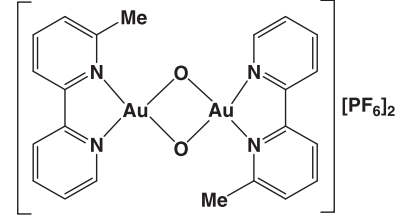

Auoxo3 $\left[\{(6-\text { Mebipy }) \mathrm{Au}\}_{2}(\mathrm{~m}-\mathrm{O})_{2}\right]\left(\mathrm{PF}_{6}\right)_{2}$

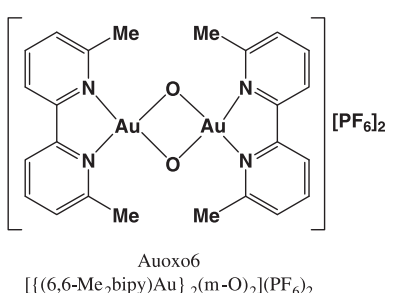

Figure 4. Schematic drawings of the dinuclear gold(III) complexes Auoxo. Auoxo3 is a ca. 1:1 mixture of the cis- and transisomer, while Auoxo4 and Auoxo5 are, as depicted, only trans-isomers.

activity. The positive correlation between the oxidizing power and the antiproliferative effects seems to be of particular interest. ${ }^{8}$

\section{TRANSPORT, BIODISTRIBUTION, AND BIOTRANSFORMATION OF GOLD COMPOUNDS}

A variety of chemical, biochemical, and biological studies (both in animals and in patients) indicate that gold(I) compounds - in clinical use for as long as antiarthritic agents - are prodrugs as they must undergo specific chemical transformations to generate their pharmacologically active species. ${ }^{2,21}$ These chemical transformations usually consist of fast ligand exchange reactions. A number of important gold metabolites may be produced as well. Thus, $\left[\mathrm{Au}(\mathrm{CN})_{2}\right]^{-}$(aurocyanide), gold-glutathione complexes, and gold-protein adducts seem to play major roles in the overall in vivo metabolism of gold compounds. ${ }^{2}$ Detailed information is available on the metabolism, transport, and biodistribution of gold(I) complexes in relation to several studies carried out so far on antiarthritic gold(I) drugs. Details will be described below. Conversely, only limited data are available regarding the metabolism of experimental gold(III) compounds and their intracellular disposition and fate. In any case, various bioinorganic studies performed on gold(III) metallodrugs in recent years point out that gold(III) compounds exhibit, on the whole, relevant reactivity with several biomolecules consisting of either ligand exchange processes or redox processes. Depending on the specific nature of the various gold(III) complexes, their electrochemical profile, and the type of reacting species, these reactions may lead either to the formation of tight gold(III)-biomolecule coordinative bonds or to the oxidation and damage of the involved biomolecule itself. ${ }^{9}$

Due to the high affinity of the "soft" gold(I) center for sulfur and selenium ligands, proteins (e.g. enzymes, transport proteins) bearing accessible side chains like cysteine, methionine, and selenocysteine constitute preferential targets for gold(I) compounds. ${ }^{1}$ However, gold(I) coordination to imidazole groups of histidines is also possible. Commonly, reactions of gold drugs or their metabolites with proteins result in the formation of tight gold-protein adducts so that gold is usually associated with high-molecular-weight components. ${ }^{9}$

Gold(I) thiolate drugs as well as gold(I) phosphines have been reported to undergo important ligand exchange reactions with the tripeptide glutathione or with proteins like 
albumin and metallothioneins (MTs). ${ }^{22-24}$ Gold(I) is thermodynamically more stable than gold(III). However, in the lysosomes of activated macrophages and granulocytes, i.e. one of the main intracellular storage sites for gold compounds, injected gold(I) drugs may be oxidized to gold(III) by hypochlorite (generated by myeloperoxidase). ${ }^{25,26}$ This represents an effective and unexpected biochemical pathway whereby the usually unstable gold(III) species are formed in vivo.

Much attention has been focused on the study of the reactions of gold(I) compounds with serum albumin, a protein abundant in the blood, which can transport metal compounds (Fig. 5). Among the several cysteine residues present in the serum albumin, the low $\mathrm{p} K_{\mathrm{a}}$ cysteine-34, which is predominantly deprotonated at the physiological $\mathrm{pH}$, seems to be the most likely anchoring site for gold drugs in the blood. The coordination of aurothiomalate to cysteine-34 to form albumin-S-Au-STm and albumin-S-(Au- $\mu \mathrm{STm})_{n}$-Au-STm is supported by chemical evidence. ${ }^{27}$

Much is known about the reaction of auranofin with serum albumin. A ligand exchange reaction of auranofin with cysteine-34 displaces its original thiol ligand-i.e. the tetraacetylthioglucose ligand. ${ }^{27-31}$ In addition, a conformational change in albumin, which accompanies gold binding to cysteine-34, has been described. ${ }^{32}$ In turn, the tetraacetylthioglucose ligand released from auranofin may react further with cysteine-34 disulfide bonds to liberate cysteine ${ }^{33}$; the triethylphosphine $\left(\mathrm{Et}_{3} \mathrm{P}\right)$ ligand, once released from auranofin, is rapidly oxidized to triethylphosphine oxide $\left(\mathrm{Et}_{3} \mathrm{PO}\right){ }^{34}$

Physiological low-molecular-weight thiol ligands like glutathione may induce the displacement of phosphine ${ }^{34,35}$ and its oxidation. The oxidant for phosphine can be either molecular oxygen or albumin disulfide bonds. ${ }^{36}$ As free oxygen is not present in the serum, it is likely that disulfide bonds are the actual in vivo oxidants. ${ }^{36}$

The three components of auranofin are thus metabolized very differently in vivo: triethylphosphine oxide and the thiol ligand are excreted with half-lives of 8 and $16 \mathrm{hr}$, respectively, while the half-life for gold excretion is about 20 days. ${ }^{37}$ When auranofin is added to whole blood, ligand displacement reactions are extremely rapid. Within $20 \mathrm{~min}$, gold is primarily protein bound in the serum, while $\mathrm{Et}_{3} \mathrm{P}$ is distributed in 1:2:2 ratio among serum proteins, red cells, and $\mathrm{Et}_{3} \mathrm{PO},{ }^{38}$ which is then excreted by the kidneys. ${ }^{39}$

In animal models, gold(I) compounds are known to bind strongly and extensively to MT, a heavy-metal binding protein that is abundant in mammalian kidney and liver ${ }^{40}$ (Fig. 5). Under normal physiological conditions, MT can bind seven $\mathrm{Zn}$ (II) or $\mathrm{Cd}(\mathrm{II})$ ions in the two metal clusters generated from its 20 cysteine residues. MT is found to manifest a high affinity for gold(I) and to displace the thiomalate ligand from AuSTm; the resulting protein-bound gold is coordinated with two cysteine residues to form Au,Cd-MT or Au, Cd,Zn-MT clusters, depending on the initial metal loading of $\mathrm{MT} .{ }^{41}$ In view of these interesting results it seems very likely that MT plays a crucial role in the intracellular gold storage and metabolism.

Gold(I) drugs may also be activated through conversion to $\mathrm{Au}(\mathrm{CN})_{2}^{-}$, a common metabolite for gold(I) compounds, which is normally recovered in the blood and urine of goldtreated patients. ${ }^{2} \mathrm{Au}(\mathrm{CN})_{2}^{-}$may be produced by two processes involving the formation of hypothiocyanide and hypochlorous acid. $\mathrm{Au}(\mathrm{CN})_{2}^{-}$is known to be an inhibitor of the respiratory burst of neutrophils and monocytes and of lymphocyte proliferation. The neutrophil enzyme myeloperoxidase may convert gold thiomalate to $\mathrm{Au}(\mathrm{CN})_{2}^{-}$through the oxidation of thiocyanate. $^{42}$

As previously mentioned, gold(III) is apparently an intermediate metabolite formed in vivo through the oxidation of gold(I). The oxidation of gold(I) to gold(III) for sodium aurothiomalate seems to be responsible for the adverse immune reactions that may develop during gold therapy. ${ }^{43}$ In vitro studies with phagolysosomes suggest the presence of a redox system and the formation of gold(III) from gold(I) following an oxidative burst in phagocytic 
a)
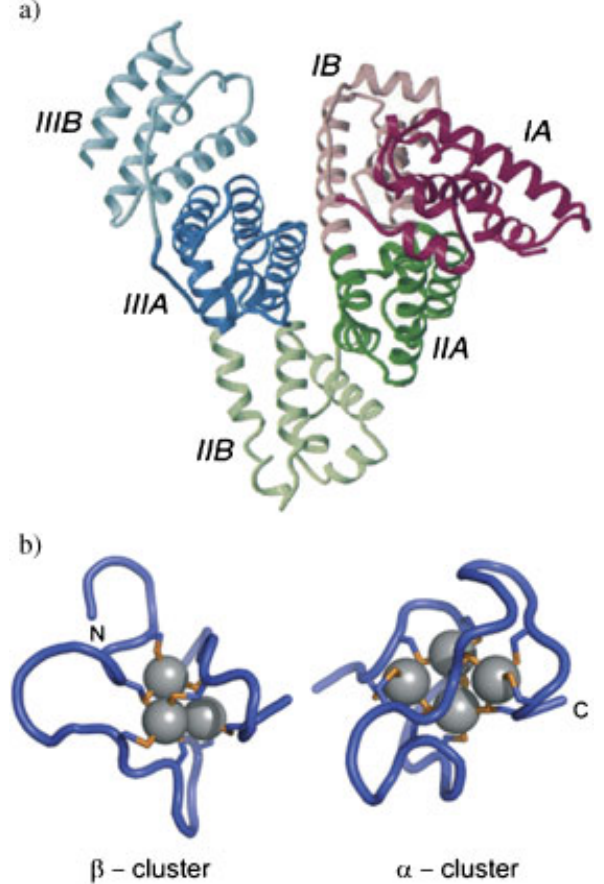

Figure 5. Molecular structures of (a) human serum albumin (reprinted from Curry et al., BBA---Mol Cell Biol Lipids 1999;1441:131-140. Copyright 1999, with permission from Elsevier) and (b) metallothionein-2 (from rat liver), two proteins that are primarily involved in gold transport and storage.

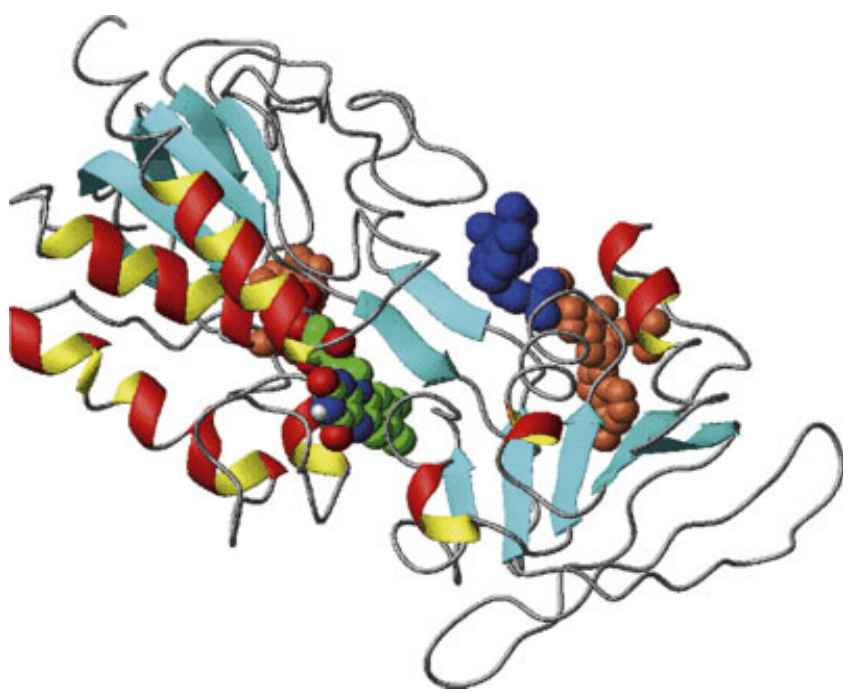

Figure 6. Schematic representation of the molecular structure of mammalian thioredoxin reductase TrxR1 (reprinted from Casini et al. ${ }^{9}$. Copyright 2008, with permission from Elsevier).

immune cells. ${ }^{44}$ Conversely, the reduction of $\mathrm{AuCl}_{3}$ and of its derivatives by serum albumin and by a variety of thiols and thioethers occurs over longer time periods compared with the hypochlorite oxidation of gold(I). ${ }^{44}$ 
Overall, the described results point out that gold(I) drugs have a rich and complex coordination chemistry inside cells and may undergo a variety of chemical transformations, mainly driven by the intracellular thiols. The interplay of gold between the oxidation states +1 and +3 has been conclusively demonstrated. Some studies have described the interactions of gold drugs with membranes. Due to the presence of solubilizing groups, gold(I) thiolates (including aurothiomalate and aurothioglucose) are water soluble compounds; therefore, they do not enter cells, but rather bind to the cell membrane via cell surface thiols. Consequently, these drugs may affect cell metabolism either by interfering with normal cell signalling pathways or by starving cells through inhibition of nutrient uptake. ${ }^{22,45,46}$

The mechanism of transport of auranofin metabolites (i.e. $\mathrm{Au}(\mathrm{CN})_{2}^{-}$) has been investigated in depth by Snyder et al. ${ }^{47}$ in cultured macrophage cells. They postulate the thiolshuttle (or the sulfhydryl-shuttle) model for gold entry inside cells. Auranofin reaches the membrane of various cell types unmodified. ${ }^{37,47,48}$ Sulfhydryl-dependent membrane transport proteins provide a vehicle for the movement of the $\mathrm{Et}_{3} \mathrm{PAu}^{+}$cation across the cell membrane, whereas the thiolate ligand remains outside the cell. Then, the cation is transferred to proteins and to low-molecular-weight thiols while the phosphine is oxidized to $\mathrm{Et}_{3} \mathrm{PO}$. Either bound or unbound to phosphine, the gold ion can be shuttled out of the cell

the same way as it enters it. ${ }^{47,48}$ At this time, gold may still be bound to an intracellular thiol (albumin or glutathione). Once outside the cell, gold again binds to an extracellular thiol (e.g. albumin), resulting in the formation of a complex constituted by albumin, gold, and an intracellular thiol. This complex may represent the major circulating metabolite of auranofin. Membrane transport proteins that mediate gold uptake are not an energy-dependent active transport process. ${ }^{47}$ Thus, the hypothesis of a possible equilibrium between intracellular gold concentrations and extracellular gold sources has been successfully investigated. ${ }^{48}$

\section{CELLULAR AND MOLECULAR TARGETS OF GOLD COMPOUNDS}

Due to the numerous in vitro studies that have appeared on gold compounds in the last decade, a number of specific hypotheses have been formulated concerning their possible mode of action. Nevertheless, the molecular mechanisms responsible for their biological effects are still largely unknown. The conspicuous amount of pharmacological data now available for a variety of gold compounds has led to the identification of a few crucial cellular processes, likely involved in their cytotoxic actions, which should be further explored. In particular, direct DNA damage, modification of the cell cycle, mitochondrial damage, proteasome inhibition, modulation of specific kinases, and other cellular processes affected by gold compounds, which eventually trigger apoptosis, seem to play a major role in the mechanism of action of gold compounds. The main postulated biomolecular targets and biochemical mechanisms that emerge from those investigations are reviewed below.

Overall, from a detailed analysis of the mechanistic studies carried out so far on the biological reactions of gold compounds, it is possible to define three major classes according to their mode of action with biological targets.

(1) Gold compounds are prodrugs capable of coordinating tightly to biomolecules' side chains, e.g. thiols, imidazole, and selenols, after activation (usually through the release of a labile ligand), e.g. auranofin. This behavior involves an alkylation mechanism similar to that of the platinum compounds.

(2) Gold complexes are big cations capable of crossing membranes and of binding noncovalently but strongly to biomolecules (proteins, enzyme, DNA) (coordination 
compounds that target biomolecules) e.g. gold-based DNA intercalators, gold(III) porphyrins.

(3) Gold compounds that react with biomolecules mainly through redox chemistry causing oxidative damage e.g. Auoxo6.

\section{A. DNA as a Target}

Initially, mechanistic studies on gold compounds have focused on DNA and RNA as these biomolecules are commonly considered to be the major targets for anticancer platinum drugs. However, weak interactions occurring in vitro between antiarthritic gold(I) drugs and DNA in early studies were confirmed in later studies, disclosing the possibility that different cellular processes might be involved in the cytotoxic mechanism of gold(I) drugs. ${ }^{49}$ In turn, the marked "soft" character of the gold(I) center makes a selective and tight reaction with the nitrogen donors of nucleobases rather unlikely; recent studies revealing strong interactions of gold(I) drugs with specific protein side chains such as thiols and selenols rather than with nucleobases indirectly support that early view. 5,50

More extensive studies have been carried out on the reactions of gold(III) compounds with DNA upon consideration of the "harder" character of the gold(III) center and of its high propensity to react with nucleobase nitrogens. Significantly stronger interactions with DNA and DNA nucleobases are highlighted in comparison with gold(I) drugs. As gold in the +3 oxidation state is isoelectronic $\left(\mathrm{d}^{8}\right)$ with platinum(II) and forms square planar complexes, cisplatin is the obvious comparative drug for most of the mechanistic studies carried out on gold(III) complexes. However, the molecular mechanisms of gold(III) compounds and cisplatin are still quite different. Although it was suggested that possible binding sites for gold(III) compounds are the same as for platinum(II) drugs, ${ }^{51,52}$ it still remains to be seen to what extent gold(III) compounds react with DNA and not with other intracellular targets (i.e. proteins or low-molecular-weight thiols).

We analyzed the interactions of a series of structurally different gold(III) compounds with DNA in detail using several physicochemical techniques. Our studies reveal that the in vitro interactions of mononuclear bipyridyl gold(III) complexes (such as $\left[\mathrm{Au}(\right.$ bipy $\left.)(\mathrm{OH})_{2}\right]\left[\mathrm{PF}_{6}\right]$ and $\left[\mathrm{Au}\left(\right.\right.$ bipy $\left.\left.\left.^{\mathrm{c}}-\mathrm{H}\right)(\mathrm{OH})\right]\left[\mathrm{PF}_{6}\right]\right),{ }^{53}$ of polyamine complexes (such as $\left[\mathrm{Au}(\mathrm{en})_{2}\right] \mathrm{Cl}_{3}$ and $\left.[\mathrm{Au}(\mathrm{dien})-\mathrm{Cl}] \mathrm{Cl}_{2}\right),{ }^{54}$ and of a series of dinuclear oxo gold(III) complexes bearing bipyridyl ligands ${ }^{55}$ with calf-thymus DNA are usually weak and reversible, suggesting that they are mainly electrostatic in nature. However, there are some notable exceptions. $\left[\mathrm{Au}_{2}\left(6,6^{\prime}\right.\right.$-dimethyl-2,2'-bipyridine $\left.)(\mu-\mathrm{O})_{2}\right]\left[\mathrm{PF}_{6}\right]_{2}$ is reported to give rise to specific redox processes and to bind firmly to the DNA double helix. ${ }^{55}$ Also, chloroglycylhistidine gold(III) compounds are reported to bind DNA tightly and modify appreciably its conformation. ${ }^{56}$ The case of a gold(III) terpyridine (Terpy) complex, $\left[\mathrm{AuCl}(\mathrm{Terpy}) \mathrm{Cl}_{2}\right.$, a gold(III) analogue of $[\mathrm{PtCl}(\mathrm{Terpy})] \mathrm{Cl}$, endowed with very relevant cytotoxic properties ${ }^{15}$ merits more extensive analysis. This complex was investigated to establish whether it may act as an intercalating agent like [ $\mathrm{PtCl}($ Terpy)]. In spite of their close structural similarity, the comparative study of the interactions of both compounds with double-stranded DNA shows that they produce quite different DNA interaction patterns. It also emerges that the resulting metal/DNA interaction patterns depend on the applied incubation times. Remarkably, [PtCl(Terpy)]Cl quickly intercalates DNA; then, coordinative bonds form progressively over time. At variance, $\left[\mathrm{AuCl}(\right.$ Terpy) $] \mathrm{Cl}_{2}$ first interacts electrostatically with the DNA surface, with subsequent slow formation of some coordinative bonds. ${ }^{57}$

A recent study shows that the level of DNA metallation induced by two gold(III) terpyridine complexes is comparable to that of DNA platination by trans-platinum 
complexes. ${ }^{58}$ In addition, the same authors found that for complexes bearing a different positive charge, a higher positive charge enhances the DNA binding affinity. The main interactions of these complexes with DNA are ascribed to the intercalation of the square planar gold(III) chromophore into the DNA double helix.

DNA binding affinity studies performed using purified calf-thymus DNA on some gold(III) dithiocarbamate derivatives (i.e. [Au(DMDT) $\left.\mathrm{X}_{2}\right]$ where DMDT is $N, N$-dimethyldithiocarbamate and $\left[\mathrm{Au}(\mathrm{ESDT}) \mathrm{X}_{2}\right]$ where ESDT is ethylsarcosinedithiocarbamate; $\mathrm{X}=\mathrm{Cl}$ or $\mathrm{Br}$ ) show that they possess an appreciable affinity for the DNA double helix with some evidence of binding being achieved soon after mixing. ${ }^{59}$ Thus, the studied gold(III) dithiocarbamate derivatives appear to be more efficient in inducing interstrand cross-links than cisplatin itself. In particular, gold(III)-DNA adducts are formed with faster kinetics compared with cisplatin but turn out to be less stable. ${ }^{59}$ Notably, the resulting DNA lesions are very efficient in killing cells.

There is much recent attention focused on the analysis of the interactions of cytotoxic gold(III) porphyrins with DNA. The first mechanistic studies on gold(III) porphyrins (using gold(III) mesotetraarylporphyrins) show that they interact strongly and directly with DNA, ${ }^{17}$ implying that DNA may actually constitute a preferential biomolecular target. However, in a successive study, the same authors reveal that gold(III) porphyrin 1a acts differently from cisplatin in vivo as the gold compound causes DNA fragmentation rather than cross-linkage; moreover, its interactions with DNA are reported to be noncovalent and reversible in nature. ${ }^{60}$

It seems reasonable to conclude that DNA is neither the primary nor the exclusive target for most gold(I) and gold(III) complexes. A strong gold association with DNA has been demonstrated only in a few cases, in particular those where the interaction is mainly dependent on the nature of the ligand (as is the case for gold porphyrins and gold terpyridines). Accordingly, the relevant cytotoxic effects induced by gold compounds must logically arise from their ability to interfere with distinct cellular processes and targets. ${ }^{61}$ A few relevant targets for gold compounds, mainly protein targets, have clearly emerged during the last years and are described below.

\section{B. Proteins as Targets: Inbibition of Thioredoxin Reductase}

The action of gold compounds on the enzyme thioredoxin reductase, now described in depth, might explain the relevant alterations observed in mitochondrial functions (e.g. permeability transition) after gold treatment. ${ }^{62,63}$ The thioredoxin redox system comprises thioredoxin reductase (TrxR), a homodimeric selenium containing flavoprotein, and thioredoxin (Trx), a ubiquitously expressed small protein with a conserved Cys-Gly-Pro-Cys redox catalytic site capable of reducing a variety of substrates. ${ }^{64}$ Both Trx and TrxR in mammals are expressed as dedicated isoforms for either predominantly cytosolic (Trx1 and TrxR1) (Fig. 6) or mitochondrial (Trx2 and TrxR2) localization. ${ }^{65}$ Thioredoxin plays multiple functions in the cell that include the providing of reducing equivalents for DNA synthesis through ribonucleotide reductase (RR) enzyme and for reactive oxygen species (ROS) scavenging through the peroxiredoxins (Prxs). In addition, thioredoxin is found to reduce, and thus activate, a number of transcription factors that are all involved in the regulation of various aspects of cell growth and cell survival, including $\mathrm{NF}-\kappa \mathrm{B},{ }^{66} \mathrm{AP}-1,{ }^{67} \mathrm{SP}-1$, and $\mathrm{p} 53 .{ }^{68}$

Expression levels of the cytosolic thioredoxin isoform Trx1 are increased in several human carcinomas ${ }^{69,70}$ and linked to tumor aggressiveness, and to inhibition of apoptosis. $^{71,72}$ Hence, there is great interest in the thioredoxin system as a potential target for new anticancer drugs. Both gold(I) and gold(III) compounds are found to interact strongly with the thioredoxin system as detailed below. 
As auranofin reacts mainly with thiol and/or selenol groups, it behaves as a potent and specific inhibitor of both cytosolic ${ }^{73}$ and mitochondrial TrxR, ${ }^{62,63,74}$ even in the nanomolar range. In addition to inhibition of mitochondrial TrxR, auranofin and other gold(I) compounds (e.g. aurothiomalate), at submicromolar concentrations, are shown to induce, in the presence of $\mathrm{Ca}^{2+}$ ions, mitochondrial swelling, mitochondrial membrane potential $(\Delta \psi \mathrm{m})$ decrease, and stimulation of respiration, which is dependent on membrane permeability transition, ${ }^{62}$ overall resulting in the release of cytochrome $\mathrm{c}$ into the cytoplasm. ${ }^{63,75}$ This process is crucially involved in the formation of apoptosomes and the consequent induction of apoptosis.

The ability of gold(I) compounds, in particular auranofin, to inhibit TrxR and induce apoptosis has been recently investigated in cisplatin-resistant human ovarian cancer cells. ${ }^{50}$ The treatment with auranofin of cisplatin-sensitive and -resistant ovarian cancer cells causes a consistent release of cytochrome $\mathrm{c}$ in both cell lines while cisplatin is effective only in the sensitive cells. Apoptosis is accompanied by the increased production of ROS. In resistant cells, hydrogen peroxide production is counteracted by a large overexpression of TrxR. Thus, these authors suggest that auranofin, acting as a potent inhibitor of TrxR, determines an alteration of the redox state of the cell, leading to increased production of hydrogen peroxide and to oxidation of the components of the thioredoxin system, which creates the conditions for augmented apoptosis. ${ }^{50}$ Similar studies were recently carried out by Susan Berners Price in a group of related gold(I) compounds; the main results of those studies and their unified interpretation are summarized in a review. ${ }^{7}$ The bis-chelated $\mathrm{Au}(\mathrm{I})$ bidentate phosphine complex of the water soluble ligand 1,3-bis(di-2-pyridylphosphino)propane (d2pypp), $\left[\mathrm{Au}(\mathrm{d} 2 \text {-pypp })_{2}\right] \mathrm{Cl}^{5}{ }^{5}$ as well as a number of gold(I) $N$-heterocyclic carbene complexes of the type $\left[\left(\mathrm{R}_{2} \mathrm{Im}\right)_{2} \mathrm{Au}\right]^{+76}$ are shown to selectively induce apoptosis in MDA-MB-468 human breast adenocarcinoma cells rather than in human normal breast cells (HMEC). Apoptosis is induced via the mitochondrial pathway by inhibition of both $\operatorname{Trx}$ and TrxR. ${ }^{5}$ The selective induction of apoptosis in cancer cells represents an element of particular value.

Similarly to gold(I) compounds, gold(III) compounds are known to target, rather strongly and selectively, thiol and imidazole groups of proteins (as well as selenol groups). ${ }^{9,27}$ Some gold(III) compounds developed by Cinellu et al. ${ }^{77-80}$ are shown to inhibit mitochondrial TrxR2 and to greatly perturb mitochondrial functions. ${ }^{63}$ The presumed site of interaction is the selenol moiety present in the active site of the carboxy terminus of the enzyme ${ }^{63}$ as well as other cysteine and histidine residues. These compounds, in particular Aubipy and Aubipyxil, trigger mitochondrial swelling, although to a lesser extent than auranofin, probably in relation to their different permeability characteristics. ${ }^{63}$ Also, $\Delta \psi \mathrm{m}$ is scarcely diminished by this kind of compounds.

Later on, a series of gold(III) compounds characterized by an increasing number $(n=0-3)$ of carbon-gold bonds have been reported to inhibit TrxR. ${ }^{69}$ Overall, the $\mathrm{IC}_{50}$ values for TrxR activity and for the TrxR/Trx system of the nine compounds studied ranged from 0.0022 to $1.8 \mu \mathrm{mol} / \mathrm{L}$ and from 0.18 to $>50 \mu \mathrm{mol} / \mathrm{L}$, respectively. The compound with two carbon-gold bonds is the most potent inhibitor of $\operatorname{TrxR}\left(\mathrm{IC}_{50}=0.0022 \mu \mathrm{mol} / \mathrm{L}\right)$.

$\left[\mathrm{Au}[\mathrm{DMDT}) \mathrm{X}_{2}\right]$ and $\left[\mathrm{Au}(\mathrm{ESDT}) \mathrm{X}_{2}\right]$ have been shown to inhibit both cytosolic and mitochondrial TrxR and, interestingly, the first $\left(\mathrm{IC}_{50}\right.$ values of four different compounds ranging from 5.67 to $17.01 \mathrm{nM})$ more effectively than the second $\left(\mathrm{IC}_{50}\right.$ values of four different compounds ranging from 24.74 to $35.87 \mathrm{nM}){ }^{81}$

The high selectivity of gold compounds for selenoenzymes is also suggested by the fact that the activity of glutathione reductase, a protein structurally and functionally related to TrxR but lacking selenol at the catalytic site and relying upon sulfhydryls for its catalysis, requires greater concentrations of gold compounds to be inhibited. ${ }^{73}$ In conclusion, TrxR seems to be a very specific target of gold(III) compounds as, in the same range of 
concentrations, these compounds are almost completely ineffective in altering the respiratory chain. $^{63}$

\section{Activation of Downstream Signalling Events Leading to Apoptosis}

It has been shown that auranofin-mediated generation of ROS in human promyelocytic leukemia HL-60 cells is an early event in the activation of the apoptotic cascade. Increased ROS subsequently activate p38 MAPK, which transduces a signal to the initiator caspase to triggering further proapoptotic events, which lead to caspase-3 activation, poly-ADP-ribose polymerase 1 (PARP-1) degradation, DNA fragmentation, and cell death. ${ }^{82}$

Recently, a cationic gold(I) $\mathrm{N}$-heterocyclic carbene complex, [(iPr $\left.2 \mathrm{Im})_{2} \mathrm{Au}\right] \mathrm{Cl}$, characterized by intermediate lipophilicity, has been shown to accumulate selectively in the mitochondria of tumorigenic cells (PIL cells) driven by the $\Delta \psi \mathrm{m}$. This gold(I) complex depolarizes the $\Delta \psi \mathrm{m}$, depletes the ATP pool, and activates caspase-3 and caspase-9, leading to apoptosis. ${ }^{83}$

The induction of apoptosis by mitochondrial death pathways related to ROS has been demonstrated by Wang et al. ${ }^{18}$ for gold(III) porphyrin 1a in HONE1 human nasopharyngeal carcinoma cells. These authors propose a specific and detailed model for this cellular mechanism: gold(III) porphyrin 1a directly causes depletion of the $\Delta \psi \mathrm{m}$, leading to alteration of bcl-2 family proteins (in particular suppression of bcl-2), translocation of the apoptosisinducing factor (AIF) nucleus, and release of cytochrome c. This last effect further activates caspase- 9 and caspase-3, and subsequently produces PARP-1 cleavage. Oxidative stress is likely to affect the cytotoxicity of gold(III) porphyrin 1a by regulating $\Delta \psi \mathrm{m}$.

In a successive study, the same authors identify differentially expressed proteins by comparing the protein alterations induced by either gold(III) porphyrin 1a or cisplatin treatment in the SUNE1 human nasopharyngeal carcinoma cell line. ${ }^{84} \mathrm{~A}$ wide series of protein alterations were indeed detected in this cell line after both treatments. The main alterations were found in cellular structure and stress-related chaperone proteins and in those involved in ROS (e.g. stomatin-like 2, peroxiredoxin 1 and 6, thioredoxin), in enzyme proteins and translation factors (e.g. mitochondrial single-stranded DNA binding protein$\mathrm{mtSSB}$, splicing factor 17, peptidylprolyl isomerase $\mathrm{F}$, cyclophilin $\mathrm{F}-\mathrm{CypF}$ ), in proteins that mediate cell proliferation or differentiation (e.g. cyclophilin A-CypA, porin isoform 1 voltage-dependent anion channel 1-VDAC1, calcyclin binding protein, Siah-interacting protein-CacyBP, Ras-related nuclear protein), and in proteins belonging to the internal degradation system (e.g. proteasome $\alpha$ type 3, proteasome $\beta$ type 4 , proteasome $\alpha$ type 6).

Gold(III) porphyrin 1a treatment causes cell cycle arrest initially at G2-M phase, then at G0-G1, and upregulation of the proapoptotic protein p53 in SUNE1 cells. ${ }^{60}$ Further examination of the MAPK family members shows that transient activation of $\mathrm{p} 38^{\mathrm{MAPK}}$ is involved in gold(III) porphyrin 1a-mediated cell death and that phosphorylation of $\mathrm{p} 38^{\mathrm{MAPK}}$ induced by the gold compound is enhanced by increasing concentrations of $\mathrm{H}_{2} \mathrm{O}_{2} \cdot{ }^{85}$ Overall, a differential regulation of phosphotyrosine proteins showed up related to $\mathrm{p} 38^{\mathrm{MAPK}}$ activation in gold(III) porphyrin 1a-induced signal transduction cascade. ${ }^{85}$

Based on the above reported observations, it is possible to suggest that treatment with gold(III) porphyrin 1a causes multiple effects, leading to apoptosis in the human nasopharyngeal carcinoma cell lines. The balance between pro- and antiapoptotic signals ultimately determines the survival or death of cancer cells.

The effects of gold(III) dithiocarbamate derivatives on the levels of antiapoptotic bcl-2 and proapoptotic bax in a panel of leukemia cell lines have also been analyzed. ${ }^{86}$ Short treatment $(18 \mathrm{hr})$ with $\left[\mathrm{Au}(\mathrm{MSDT}) \mathrm{Br}_{2}\right.$ ] (dibromo[methyl $N$-(dithiocarboxy-kS,kS')- $N$-methylglicinato] gold(III)) or 
[Au(MSDT)Cl $\mathrm{Cl}_{2}$ (dichloro[methyl $N$-(dithiocarboxy-kS,kS')- $N$-methylglicinato]gold(III)) is found to decrease bcl-2 and upregulate or induce bax in all cell lines examined.

Other gold(III) dithiocarbamate complexes, such as [Au[DMDT) $\left.\mathrm{X}_{2}\right]$ and $\left[\mathrm{Au}(\mathrm{ESDT}) \mathrm{X}_{2}\right]$, have been shown to trigger ROS generation and ultimately increase the levels of phosphorylated ERK1/2 through the inhibition of both cytosolic and mitochondrial TrxR2, in human uterine cervical carcinoma HeLa cells. ${ }^{81}$ The authors hypothesize that persistent ERK1/2 activation caused at first by the accumulation of hydrogen peroxide and afterward by the activation of ASK-1 may be responsible for cell death.

\section{Inbibition of the Proteasome}

The ubiquitin-proteasome pathway that is essential for many fundamental cellular processes including cell cycle regulation, apoptosis, angiogenesis, and differentiation has recently been investigated as a tumor target. Proteasome inhibitors are becoming the object of very intense research (Fig. 7). ${ }^{87}$

A gold(III) dithiocarbamate compound has been shown to inhibit, in a concentrationdependent manner, all the peptidase activities (chymotrypsin-like, trypsin-like, and PGPHlike) of a rabbit $20 \mathrm{~S}$ purified proteasome (the proteolytic core of the $26 \mathrm{~S}$ proteasome complex) with similar potencies $\left(\mathrm{IC}_{50}=7.4,10.2\right.$, and $7.0 \mu \mathrm{mol} / \mathrm{L}$, respectively $){ }^{88}$ This compound also showed the same inhibitory effects in intact MDA-MB-231 breast cancer cells. Proteasome inhibition by this compound was confirmed by decreased proteasome activity, increased levels of ubiquitinated proteins, and the proteasome target protein $\mathrm{p} 27$. Most importantly, inhibition of the proteasome activity and accumulation of p27 were also found in MDA-MB-231 xenografts treated with this gold(III) dithiocarbamate compound. Induction of apoptosis by this gold(III) dithiocarbamate compound was confirmed either in the MDA-MB-231 cell line and in the treated tumors by multiple assays that measure characteristic cellular and biochemical hallmarks. Thus, the authors suggest that proteasome could be a primary target for gold(III) dithiocarbamates both in vitro and in vivo and that inhibition of the proteasomal activity by these compounds is associated with apoptotic cancer cell death. ${ }^{88}$

\section{E. Inbibition of Protein Kinases}

Protein kinase $\mathrm{C}(\mathrm{PKC})$, a family of structurally related protein kinases, is involved in a large variety of cellular functions, including cellular proliferation, cell cycle control, differentiation, polarity, and survival. ${ }^{89}$ Altered PKC activity, localization, and/or expression have been observed in several tumor types. ${ }^{90}$ To date, several PKC isozymes have been identified as potential therapeutic targets: ${ }^{91,92}$ a number of isozyme-selective PKC inhibitors have been developed and some are already in clinical use. The atypical protein kinase $\mathrm{C}$ iota $(\mathrm{PKCl})(\mathrm{Fig} .8)$ is a bona fide human oncogene that is required for the transformed growth of human cancer cells. ${ }^{93}$

$\mathrm{PKCl}$, as well as other atypical PKCs, is structurally and functionally distinct from other PKCs as its catalytic activity does not depend upon diacylglycerol, calcium, or phosphatidylserine ${ }^{94,95}$ but may be regulated by 3 -phosphoinositides, ${ }^{96}$ phosphorylation by the phosphoinositide-dependent kinase, ${ }^{97,98}$ and through specific protein-protein interactions. ${ }^{93,99}$

It has been observed that elevated expression levels of $\mathrm{PKCl}$ play an important role in the cell growth of nonsmall cell lung cancer (NSCLC) both in vitro and in vivo by the activation of a $\mathrm{PKCl} \rightarrow \mathrm{Racl} \rightarrow \mathrm{Pak} \rightarrow \mathrm{Mek} \rightarrow$ Erk signalling axis. ${ }^{100}$ The Phox Bem 1 (PB1) domain is a structurally conserved, protein-protein interaction domain that is present in a family of signalling molecules, including $\mathrm{PKCl}$.

Upon considering the relevant role that cysteine residues usually play in interactions with gold compounds, it was investigated whether the PB1 domain interactions between the po- 


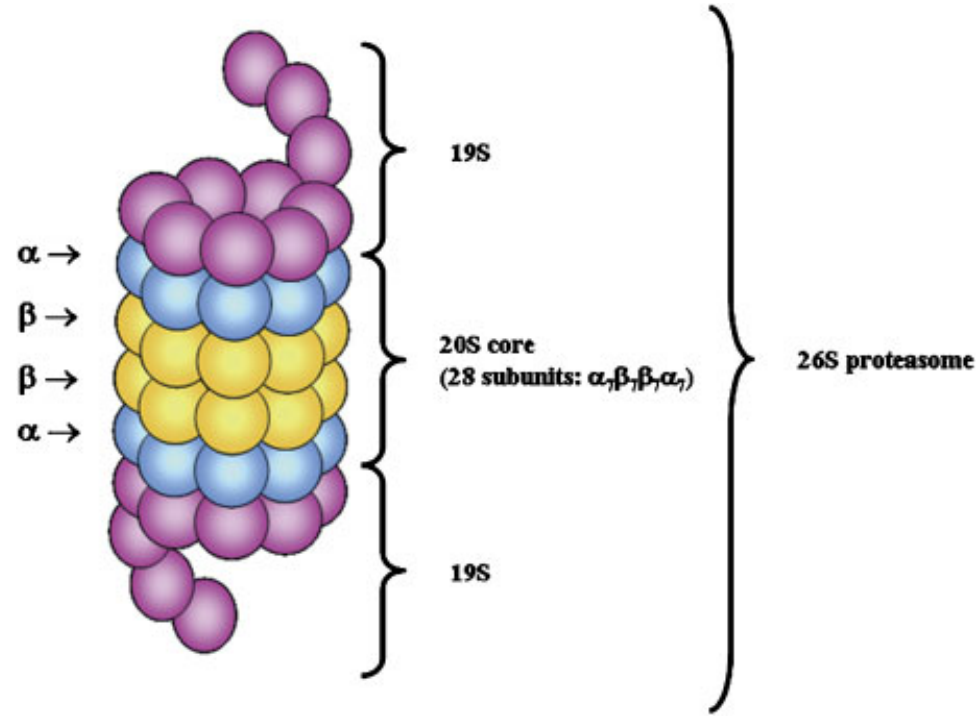

Figure 7. Schematic representation of the proteasome. It consists of a 28-subunit catalytic core (20S proteasome) and two multisubunit ATPase-containing PA700(19S) regulators. The 20S core is composed of two outer and two inner rings. Each of the two inner rings consists of seven different $\beta$-subunits, which contain the three different catalytic sites (caspase-like, trypsin-like, and chymotrypsin-like sites). Each of the two outer rings is composed of seven different $\alpha$-subunits, none of which have catalytic activity, but which serve as an anchor for the 195 regulators.

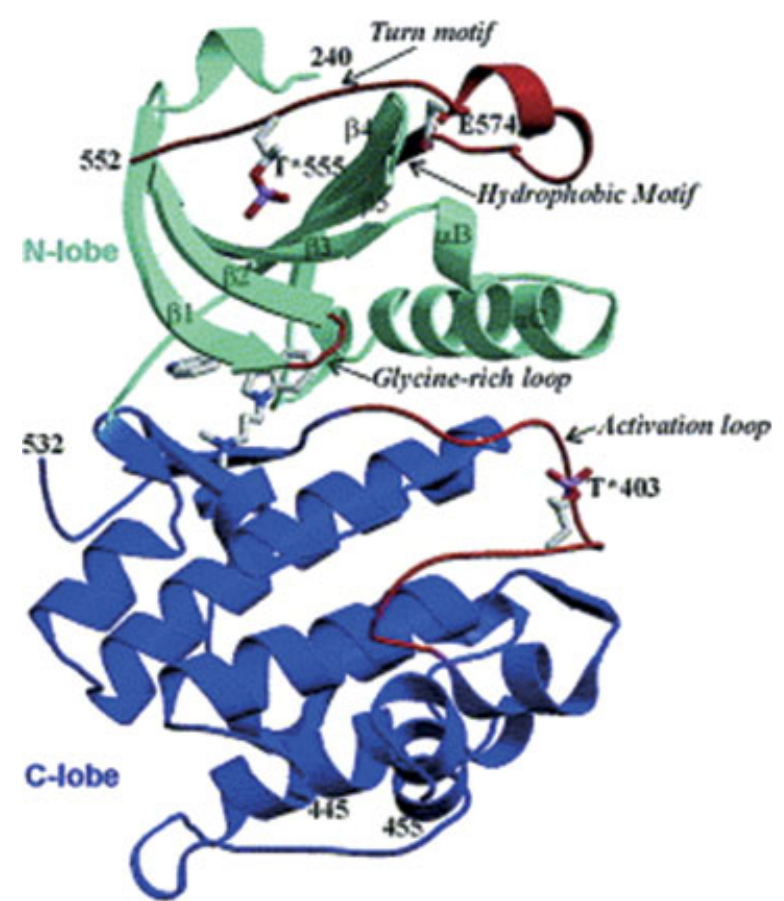

Figure 8. Ribbon plot of the $\mathrm{PKCl}$ catalytic domain structure. The $\mathrm{N}$-lobe is cyan and the C-lobe is blue. The glycine-rich loop, activation loop, turn motif, and HM segment are displayed in red. BIM1 and phosphorylated residues are given in stick representation (reprinted from Messerschmidt et al., J Mol Biol 2005;352:918-931. Copyright 2005, with permission from Elsevier). PKC1, protein kinase C iota. 
larity protein par6 containing cysteine residue and $\mathrm{PKCl}$, in human A549 NSCLC cells, might represent a potential target for aurothiomalate and aurothioglucose. ${ }^{93,101,102}$ Results indicate that both compounds act as potent inhibitors of $\mathrm{PKC1}$-par6 interaction in vitro $\left(\mathrm{IC}_{50} \sim 1 \mu \mathrm{M} / \mathrm{L}\right)$. Aurothioglucose blocks $\mathrm{PKCl}$-dependent signalling to Racl and inhibits transformed growth of NSCLC cells. ${ }^{102}$ Aurothiomalate can form gold-cysteine adducts on target cellular proteins, in particular with a critical cysteine residue, Cys69, located within the active site of the enzyme. The adduct at Cys69 protrudes into the binding cleft normally occupied by par6. These authors conclude that the selective targeting of Cys69 within the $\mathrm{PB} 1$ domain of $\mathrm{PKCl}$ might explain the inhibition of cellular transformation by aurothiomalate. ${ }^{93,101}$

\section{PRECLINICAL STUDIES}

\section{A. In Vitro Studies}

Early studies indicate that auranofin has in vitro anticancer activity similar to that of cisplatin. ${ }^{103,104}$ A systematic investigation of the cytotoxic activity of auranofin and a variety of its analogues in murine P388 leukemia and B16 melanoma cell lines shows that compounds containing both phosphine and thioglucose ligands are the most potent $\left(\mathrm{IC}_{50} \leq 10 \mu \mathrm{M}\right) .^{104}$

Another phosphine gold compound, $\mu-[1,2-b i s$ (diphenylphosphino) ethane $]$ bis $[(1-$ thio- $\beta$ D-glucopyranosato-S)gold(I)] complex with $\mathrm{IC}_{50}$ values in the micromolar range (from 4 to $11 \mu \mathrm{M})$ toward a panel of tumor cisplatin-sensitive cell lines, ${ }^{105}$ displays similar cytotoxic activity even in cisplatin-resistant cell lines. ${ }^{106}$

Gold phosphine compounds containing a variable number of coordinated phosphorus atoms (from 1 to 4) show increased cytotoxic potency in murine tumor cell lines as the number of gold-coordinated phosphorus atoms increases. ${ }^{107,108}$

Unfortunately, after relatively encouraging studies on selected tumor cell lines, ${ }^{109-112}$ auranofin analogues containing thiolate ligands derived from thionucleobases (phosphine gold(I) thionucleobase compounds) have not demonstrated marked cytotoxic activity when screened through the National Cancer Institute's panel of 60 tumor cell lines. ${ }^{113}$ However, related phosphine gold(I) thiolates show higher cytotoxic activity compared with cisplatin and 5-fluorouracil in seven human solid tumor cell lines. ${ }^{114}$

Gold(I) dithiocarbamate derivatives (DMDTM gold derivatives) have no or modest cytotoxic activity against highly sensitive human promyelocytic leukemia HL-60 cells. ${ }^{16}$

At present, the cytotoxic activity of a relatively wide number of gold(III) complexes has been evaluated. The possibility of combining gold(III) compounds with nitrogen-containing ligands derived from biologically active molecules such as streptonigrin, ${ }^{115}$ uracil, ${ }^{116}$ and glycylhistidine ${ }^{56}$ has led to the synthesis of several gold(III) compounds. The gold(III) streptonigrin complex shows inhibitory values of $0.05 \mathrm{mg} / \mathrm{mL}$ against P388 leukemia cells. ${ }^{115}$ Gold(III) compounds containing uracil derivatives show growth inhibition values ranging from 11.0 to $74.5 \%$ in the HeLa cell line. ${ }^{116}$ The chloroglycylhistidinate gold(III) compound has been investigated both in cisplatin-sensitive and -resistant human ovarian carcinoma cell lines (A2780/S and A2780/R, respectively) and is more active than cisplatin in the resistant cell line. ${ }^{56}$

A wide series of compounds containing imine and amine ligands have also been assayed. Gold compounds synthesized by Cossu et al. ${ }^{117}$ show higher cytotoxic activity than carboplatin both in A2780/S and A2780/R and mouse leukemia (L1210/S and L1210/R) cell lines. Cisplatin is more active than gold compounds in both sensitive cell lines (Table I). 
Square planar gold(III) complexes containing at least two gold-chloride bonds in cisposition produce significant cytotoxic effects in the human cisplatin-resistant CCRF-CEM/R (leukemia) and A2780/R lines. ${ }^{118}$ Some compounds are also more active than cisplatin in the A2780 cisplatin-sensitive cells (Table II).

The A2780/S and A2780/R cell lines have also been used to evaluate the cytotoxic effects of a series of classical gold(III) complexes (Table III). ${ }^{15}$ Most of these compounds manifest a relevant cytotoxicity with $\mathrm{IC}_{50}$ values generally falling in the low micromolar range. In particular, [Au(terpy)Cl] $\mathrm{Cl}_{2}$ turns out to be more active than cisplatin both in $\mathrm{A} 2780 / \mathrm{S}$ and in $\mathrm{A} 2780 / \mathrm{R}$ and $\left[\mathrm{Au}(\mathrm{phen}) \mathrm{Cl}_{2}\right] \mathrm{Cl}$ only in the resistant cell line (Table III).

Cytotoxic effects of several organogold(III) compounds have also been analyzed. Organogold(III) DAMP were the first ones studied. ${ }^{119,120}$ At a primary screening conducted against a panel of seven human tumor cell lines, $\left[\mathrm{AuCl}_{2}(\mathrm{damp})\right]$ produced cytotoxic effects similar to those of cisplatin with the breast carcinoma ZR-75-1 cell line being the most sensitive $\left(\mathrm{IC}_{50} 11 \mu \mathrm{M}\right) .{ }^{119}$ However, four additional organogold(III) DAMP compounds failed to show higher activity than cisplatin both in cisplatin-sensitive and -resistant cell lines (Table IV). ${ }^{120}$

Bipyridyl gold(III) compounds have relevant cytotoxic effects against A2780/S, A2780/R, SKOV3 (this latter inherently resistant to cisplatin) human ovarian carcinoma cell lines and the CCRF-CEM cell line, either sensitive (CCRF-CEM/S) or resistant (CCRF$\mathrm{CEM} / \mathrm{R})$ to cisplatin. In particular, $\left[\mathrm{Au}\left(\right.\right.$ bipy $\left.\left.^{\mathrm{c}}-\mathrm{H}\right)(\mathrm{OH})\right]\left[\mathrm{PF}_{6}\right]$ is markedly more active than cisplatin in A2780/R (Table V). ${ }^{53}$

Table I. In Vitro Growth Inhibition ( $\left.\mathrm{IC}_{50} \mu \mathrm{M}\right)$ of Tumor Cell Lines by Gold(III) Compounds Containing Imine Ligands (General Formula $\left[\mathrm{Au}\left(\mathrm{NR}^{n}\right) \mathrm{Cl}_{3}\right]^{117}$

\begin{tabular}{lcccc}
\hline Compound & $\mathrm{A} 2780 / \mathrm{S}$ & $\mathrm{A} 2780 / \mathrm{R}$ & $\mathrm{L} 1210 / \mathrm{S}$ & $\mathrm{L} 1210 / \mathrm{R}$ \\
\hline$\left[\mathrm{Au}\left(\mathrm{NR}^{10}\right) \mathrm{Cl}_{3}\right]$ & 14.3 & $31.2(2.2)$ & 19.4 & $18.3(0.94)$ \\
{$\left[\mathrm{Au}\left(\mathrm{NR}^{11}\right) \mathrm{Cl}_{3}\right]$} & 22.0 & $23.4(1.1)$ & 12.8 & $11.2(0.87)$ \\
{$\left[\mathrm{Au}\left(\mathrm{NR}^{12}\right) \mathrm{Cl}_{3}\right]$} & 14.9 & $16.9(1.1)$ & 14.0 & $12.4(0.88)$ \\
Cisplatin & 8.3 & $55.7(6.7)$ & 3.3 & $28.7(8.7)$ \\
Carboplatin & 119.9 & $894.8(7.5)$ & 67.6 & $258.8(3.8)$ \\
\hline
\end{tabular}

( ) resistance index $=I C_{50}$ (resistant line) $/ I_{50}$ (sensitive line). A2780, human ovarian carcinoma; L1210, murine leukemia; $\mathrm{S}$, sensitive to cisplatin; $\mathrm{R}$, resistant to cisplatin.

Table II. In Vitro Growth Inhibition ( $\left.\mathrm{IC}_{50} \mu \mathrm{M}\right)$ of Tumor Cell Lines by Gold(III) Compounds Containing At Least Two Gold-Chloride Bonds ${ }^{\text {a118 }}$

\begin{tabular}{lccccccc}
\hline Compound & A2780/S & A2780/R & SKOV3 & HEC1-A & HCT-8 & CCRF-CEM/S & CCRF-CEM/R \\
\hline $\mathrm{AuCl}_{3}(\mathrm{Hpm})$ & 10.10 & $21.0(2.1)$ & 30.50 & 21.50 & 29.0 & 17.80 & $36.30(2.0)$ \\
$\mathrm{AuCl}_{2}(\mathrm{pm})$ & 6.90 & $16.30(2.4)$ & 33.30 & 17.30 & 28.50 & 23.30 & $36.30(1.5)$ \\
$\mathrm{AuCl}_{2}(\mathrm{mesal})$ & 2.80 & $3.70(1.3)$ & 13.20 & 11.80 & 11.60 & 2.0 & $13.60(6.8)$ \\
$\mathrm{AuCl}_{2}(\mathrm{esal})$ & 2.10 & $3.80(1.0)$ & 13.50 & 14.10 & 8.0 & 5.0 & $10.80(2.2)$ \\
$\mathrm{Na}\left[\mathrm{AuCl}_{4}\right]$ & 11.0 & $17.70(1.8)$ & 42.0 & 12.60 & 26.50 & 22.50 & $35.50(1.6)$ \\
$\mathrm{Cisplatin}$ & 5.30 & $41.70(7.9)$ & 24.50 & 6.40 & 3.90 & 1.50 & $44.80(29.9)$ \\
\hline
\end{tabular}

( ) resistance index $=I \mathrm{I}_{50}$ (resistant line) $/ \mathrm{IC}_{50}$ (sensitive line). A2780, SKOV3, human ovarian carcinoma; HEC1-A, human endometrial carcinoma; HCT-8, human colon cancer; CCRF-CEM, human leukemia; S, sensitive to cisplatin; $R$, resistant to cisplatin.

a72-hr drug exposure. 
Table III. In Vitro Growth Inhibition ( $\mathrm{IC}_{50} \mu \mathrm{M}$ ) of Tumor Cell Lines by Gold(III) Compounds Containing Amine Ligands ${ }^{\mathrm{a}} 15$

\begin{tabular}{lcc}
\hline Compound & $\mathrm{A} 2780 / \mathrm{S}$ & $\mathrm{A} 2780 / \mathrm{R}$ \\
\hline$\left[\mathrm{Au}(\text { en })_{2}\right] \mathrm{Cl}_{3}$ & 8.36 & $17.0(2.03)$ \\
{$[\mathrm{Au}($ dien $) \mathrm{Cl}] \mathrm{Cl}_{3}$} & 8.2 & $18.7(2.28)$ \\
{$\left[\mathrm{Au}(\right.$ cyclam $\left.) \mathrm{ClO}_{4}\right] \mathrm{Cl}$} & 99.0 & $>120$ \\
{$\left[\mathrm{Au}(\right.$ terpy $\left.) \mathrm{Cl}_{2}\right] \mathrm{Cl}_{2}$} & 0.2 & $0.37(1.23)$ \\
{$\left[\mathrm{Au}(\right.$ phen $\left.) \mathrm{Cl}_{2}\right] \mathrm{Cl}$} & 3.8 & $3.49(0.92)$ \\
Cisplatin & 1.2 & $14(11.6)$
\end{tabular}

( ) resistance index $=1 \mathrm{C}_{50}$ (resistant line) $/ \mathrm{IC}_{50}$ (sensitive line). A2780, human ovarian carcinoma; S, sensitive to cisplatin; $R$, resistant to cisplatin.

a72-hr drug exposure.

Table IV. In Vitro Growth Inhibition $\left(\mathrm{IC}_{50} \mu \mathrm{M}\right)$ of Tumor Cell Lines by Organogold(III) Compounds With the General Formula $\left[\mathrm{AuX}_{2}(\mathrm{damp})\right]^{120}$

\begin{tabular}{|c|c|c|c|c|c|c|}
\hline Cell line & $\mathrm{X}=\mathrm{Cl}$ & $\mathrm{X}=\mathrm{SCN}$ & $\mathrm{X}=\mathrm{CH}_{3} \mathrm{CO}$ & $\mathrm{X}=\mathrm{O}_{2} \mathrm{CCH}_{2} \mathrm{CCO}_{2}$ & $\mathrm{X}=\mathrm{O}_{2} \mathrm{C}_{2} \mathrm{O}_{2}$ & Cisplatin \\
\hline \multicolumn{7}{|c|}{ Primary panel $^{\mathrm{a}}$} \\
\hline SW620 & 124.0 & 51.0 & 281.0 & 205.0 & 67.0 & 167.0 \\
\hline SW1116 & 119.0 & 47.0 & 238.0 & 215.0 & 80.0 & 163.0 \\
\hline ZR-75-1 & 27.0 & 34.0 & 45.0 & 41.0 & 36.0 & 27.0 \\
\hline HT29/219 & 55.0 & 25.0 & 67.0 & 19.0 & 36.0 & 17.0 \\
\hline HT1376 & 30.0 & 6.7 & 13.0 & 10.0 & 11.0 & 23.0 \\
\hline SKOV3 & 45.0 & 20.0 & 13.0 & 10.0 & 11.0 & 23.0 \\
\hline \multicolumn{7}{|c|}{ Ovarian carcinoma cell line panel ${ }^{\mathrm{b}}$} \\
\hline HX62 & 57.0 & 31.0 & 34.0 & 30.0 & 27.0 & 18.0 \\
\hline SKOV3 & 109.0 & 39.0 & 107.0 & 42.0 & 30.0 & 5.2 \\
\hline $\mathrm{CH} 1 / \mathrm{S}$ & 13.0 & 10.0 & 11.0 & 11.0 & 2.7 & 0.12 \\
\hline $\mathrm{CH} 1 / \mathrm{R}$ & $22.0(1.7)$ & $11.0(1.1)$ & $12.0(1.1)$ & $13.0(1.2)$ & $3.3(1.2)$ & $0.56(4.7)$ \\
\hline $\mathrm{A} 2780 / \mathrm{S}$ & 8.2 & 2.0 & 3.5 & 3.7 & 2.7 & 1.2 \\
\hline $\mathrm{A} 2780 / \mathrm{R}$ & $47.0(5.7)$ & $26.0(13)$ & $35.0(10)$ & $35.0(9.5)$ & $16.0(5.9)$ & $10.0(8.3)$ \\
\hline
\end{tabular}

( ) resistance index $=I C_{50}$ (resistant line) $/ I_{50}$ (sensitive line). SW620, SW1116, SW403, HT29/219, human colon carcinoma; ZR-75-1, human breast carcinoma; HT1376, human bladder carcinoma; A2780, SKOV3, HX62, CH1, human ovarian carcinoma; $S$, sensitive to cisplatin; $R$, resistant to cisplatin.

a 4 -hr drug exposure.

b96-hr drug exposure.

Four gold(III) compounds (AuXyl, AuTol, AuPyAcO, and $\mathrm{AuPzCl}$ ) have been screened in a panel of five human tumor cell lines. After 72-hr drug exposure, AuPyAcO and AuXyl were generally the most active, showing the highest cytotoxic activity against A2780/S (Table V). ${ }^{19}$ After shorter drug exposure $(48 \mathrm{hr})$, the same compounds and $\left[\mathrm{Au}\left(\right.\right.$ bipy $\left.\left.{ }^{\mathrm{dmd}}-\mathrm{H}\right)(\mathrm{OH})\right]\left[\mathrm{PF}_{6}\right]$ showed $\mathrm{IC}_{50}$ values comparable to those of cisplatin both in A2780/S and in A2780/R cell lines. ${ }^{20}$

Another series of dinuclear gold(III) compounds with bipyridyl ligands (Auoxo1-6) have also been evaluated in A2780/S and A2780/R ${ }^{55}$ Auoxo6 is more active than cisplatin against both cell lines (Table VI). ${ }^{55}$

Differently from gold(I) dithiocarbamate compounds, gold(III) dithiocarbamates display a very promising cytotoxic profile. ${ }^{16}$ Four DMDT and ESDT gold(III) derivatives 
NOBILI ETAL.

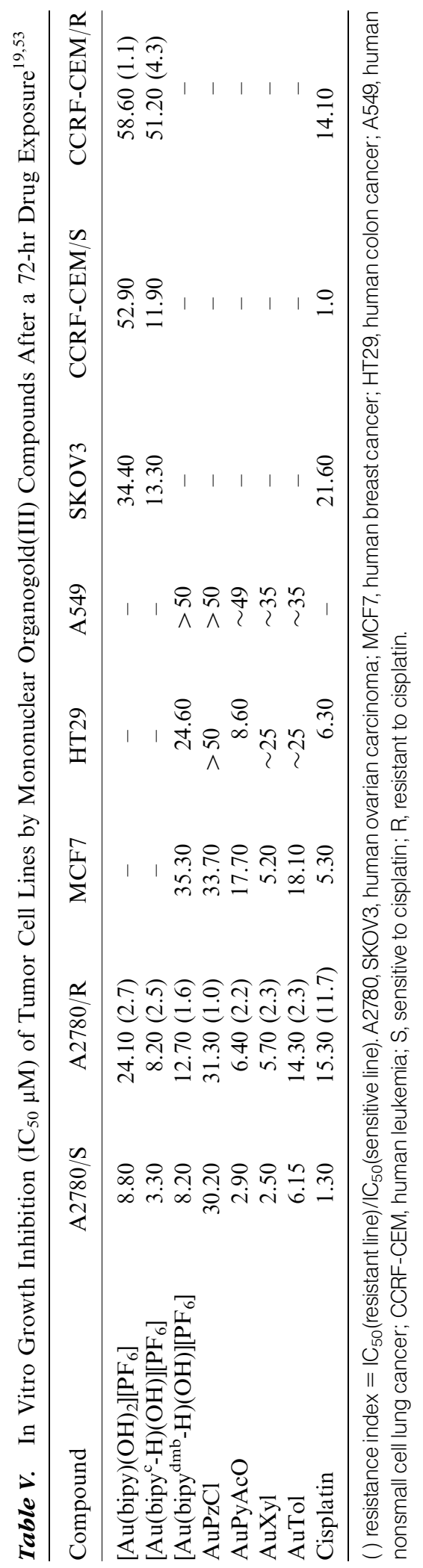


exhibit relevant cytotoxic activities toward a panel of human tumor cell lines, being far more potent than cisplatin even at nanomolar concentration (Table VII). In addition, all the tested gold(III) complexes are more cytotoxic than cisplatin on cisplatin-resistant cell lines, with activity levels comparable to those induced on the parental sensitive cell lines, ruling out the occurrence of cross-resistance phenomena (Table VII). ${ }^{16}$

The same group of authors have recently investigated the cytotoxic properties of two gold(III) methylsarcosinedithiocarbamate derivatives on a panel of human acute myeloid leukemia (AML) cells. ${ }^{86}$ [Au(MSDT)Cl $\mathrm{Cl}_{2}$ ] and $\left[\mathrm{Au}(\mathrm{MSDT}) \mathrm{Br}_{2}\right.$ ] are significantly more active than cisplatin in inhibiting the clonogenic growth of all AML cell lines in a dose-dependent manner.

Table VI. In Vitro Growth Inhibition ( $\mathrm{IC}_{50} \mu \mathrm{M}$ ) of Tumor Cell Lines by Dinuclear Organogold(III) Compounds After a 72-hr Drug Exposure ${ }^{55}$

\begin{tabular}{lcc}
\hline Compound & A2780/S & A2780/R \\
\hline Auoxo1 & 22.80 & $23.30(1.0)$ \\
Auoxo2 & 12.10 & $13.5(1.1)$ \\
Auoxo3 & 25.40 & $29.8(1.2)$ \\
Auoxo4 & 12.70 & $19.8(7.3)$ \\
Auoxo5 & 11.0 & $13.2(1.2)$ \\
Auoxo6 & 1.79 & $4.81(2.7)$ \\
Cisplatin & 2.1 & $24.4(11.6)$ \\
\hline
\end{tabular}

( ) resistance index $=I C_{50}$ (resistant line) $/ I_{50}$ (sensitive line). A2780, human ovarian carcinoma; S, sensitive to cisplatin; $R$, resistant to cisplatin.

Table VII. In Vitro Growth Inhibition $\left(\mathrm{IC}_{50} \mu \mathrm{M}\right)$ of Tumor Cell Lines by Gold(III) Compounds Containing Dithiocarbamate Ligands After a 24-hr Drug Exposure ${ }^{16}$

\begin{tabular}{lccccc}
\hline & {$\left[(\mathrm{DMDT}) \mathrm{AuCl}_{2}\right]$} & {$\left[(\mathrm{DMDT}) \mathrm{AuBr}_{2}\right]$} & {$\left[\left(\mathrm{ESDT}^{2} \mathrm{AuCl}_{2}\right]\right.$} & {$\left[(\mathrm{ESDT}) \mathrm{AuBr}_{2}\right]$} & Cisplatin \\
\hline HELA & 2.10 & 3.50 & 8.20 & 7.60 & 15.60 \\
HL-60 & $0.80 \times 10^{-2}$ & $0.10 \times 10^{-2}$ & 2.0 & 0.14 & 0.35 \\
Daudi & $0.10 \times 10^{-2}$ & $0.10 \times 10^{-2}$ & 4.65 & 5.80 & 95.0 \\
MeWo & 2.0 & $0.10 \times 10^{-2}$ & 12.50 & 10.0 & 48.0 \\
LoVo & $2.40 \times 10^{-2}$ & 3.80 & 7.60 & 7.90 & 56.0 \\
A549 & $0.35 \times 10^{-2}$ & 0.41 & 4.73 & 9.60 & 35.0 \\
2008 & $0.20 \times 10^{-2}$ & 30.10 & 49.30 & 16.50 & 43.20 \\
C13 & $0.10 \times 10^{-2}$ & 2.18 & 23.80 & $0.10 \times 10^{-2}$ & 556.0 \\
A431 & $1.20 \times 10^{-2}$ & 1.80 & 0.29 & $1.5 \times 10^{-2}$ & 77.40 \\
A431-R & $0.20 \times 10^{-3}$ & 2.80 & 0.43 & $0.10 \times 10^{-2}$ & 382.0 \\
U20S & 4.80 & 18.0 & 5.80 & 0.49 & 35.0 \\
U20S-R & 6.40 & 13.0 & 5.20 & 0.24 & 85.0 \\
\hline
\end{tabular}

HELA, human squamous cervical adenocarcinoma; HL-60, human leukemic promyelocytes; Daudi, human Burkitt's Iymphoma; MeWo, human malignant melanoma; LoVo, human colon adenocarcinoma; A549, human nonsmall cell lung adenocarcinoma; 2008, cisplatin-sensitive human ovarian carcinoma; C13*, cisplatin-resistant human ovarian carcinoma; U20S, cisplatin-sensitive human osteosarcoma; U20S-R, cisplatin-resistant human osteosarcoma; A431, cisplatin-sensitive human squamous cervix carcinoma; A431-R, cisplatin-resistant human squamous cervix carcinoma. 
Gold(III) mesotetraarylporphyrin complexes (including gold(III) porphyrin 1a) ${ }^{17}$ have been investigated in a panel of human tumor cell lines and have $\mathrm{IC}_{50}$ values ranging from 0.1 to $1.5 \mu \mathrm{M}$. Lack of cross-resistance with cisplatin was also observed. More recently, the in vitro cellular pharmacology properties of gold(III) porphyrin 1a have been more extensively investigated in a nasopharyngeal carcinoma cell line (SUNE1), ${ }^{60}$ where the higher activity of the gold compound compared with cisplatin was confirmed.

\section{B. Efficacy Data in In Vivo Studies}

Although most gold(I) compounds exhibit marked antitumor activity in vitro, very limited success has been observed in vivo. ${ }^{121}$ Efficacy data in mice inoculated with lymphocytic leukemia P388 are available for auranofin. Eight dose schedules ranging from $6 \mathrm{mg} / \mathrm{kg}$ every fourth day to $6 \mathrm{mg} / \mathrm{kg}$ twice daily for 9 days administered i.p. were used. ${ }^{122}$ Increased survival is correlated with drug dose amount and/or dose frequency. The median survival times for the groups of animals treated at higher and more frequent doses are 18.5 days $(3 \mathrm{mg} / \mathrm{kg}$, twice daily), 21 days $(4.5 \mathrm{mg} / \mathrm{kg}$, twice daily), and 22 days $(6 \mathrm{mg} / \mathrm{kg}$, twice daily) with $T / C$ (tumor/ control) ratios of 185,210 , and $220 \%$, respectively. The efficacy of auranofin in the same tumor model was only partially confirmed in the study of Mirabelli et al. ${ }^{121}$ where the optimal dose of $12 \mathrm{mg} / \mathrm{kg}$ administered i.p. (days 1-5) produced a 59\% increased life span (ILS); the drug was completely inactive when administered i.v., s.c., or p.o. Although several mouse models, including solid cancers (e.g. lung, colon, breast cancers), were used in this study, only the P388 leukemia model was sensitive to auranofin.

Other gold(I) thiolates, such as aurothioglucose and aurothiomalate, have been examined for antitumor activity. They inhibited the growth of the primary tumor and reduced lung metastases in mice bearing Lewis carcinoma. ${ }^{123}$ Aurothiomalate was less active compared with cisplatin in Balb/C mice inoculated (i.p.) with syngenic Meth/A cells, although it displayed a wider range of dose effectiveness and no significant toxicity when administered in doses up to $125 \mathrm{mg} / \mathrm{kg} /$ day. ${ }^{124}$

Aurothioglucose has been evaluated in athymic nude mice injected with A549 NSCLC cells. Once tumors were established, mice were randomized to receive aurothioglucose $20 \mathrm{mg} / \mathrm{kg}$ or diluent $(0.9 \%$ saline $)$. In the presence of aurothioglucose, A549 cell tumors exhibited a marked reduction in growth kinetics compared with controls. However, results indicate that aurothioglucose has a cytostatic rather then cytotoxic effect on A549 tumors. ${ }^{102}$

The in vivo data available for gold(III) compounds as anticancer agents are even more limited, probably due to the high redox potential and relatively poor kinetic stability of several of these compounds under physiological conditions. However, a conspicuous number of gold(III) compounds that are stable against demetallation and/or reduction under physiological conditions are today available (see "Chemistry of gold compounds" section) and their in vivo evaluation is warranted.

Efficacy and toxicity data are now available for the gold(III) porphyrins developed by Che and co-workers ${ }^{125}$ and for the gold(III) dithiocarbamates developed by Fregona and coworkers. ${ }^{88}$ The efficacy of gold(III) porphyrin 1a has been evaluated in an orthotopic rat hepatocellular carcinoma model. ${ }^{125}$ After an intratumoral injection of 0.5 or $0.75 \mathrm{mg} / \mathrm{kg}$ of gold(III) porphyrin 1a, followed by i.p. injections twice weekly to animals according to body weight until their death, survival of both groups of treated animals was significantly prolonged compared with that of the control group (median 42 and 40 vs. 30 days, $P<0.05) .{ }^{125}$ Interestingly, the tumor tissue of the treated rats contained larger areas of necrosis compared with those observed in the control group and the gold compound did not cause observable necrosis in the adjacent normal liver tissue. This last observation was 
confirmed by plasma AST levels that were lower in the treated animals compared with the control group. ${ }^{125}$

In a recent study ${ }^{88}$ the s.c. treatment of MDA-MB-231 tumor-bearing nude mice with a gold(III) dithiocarbamate compound significantly inhibited tumor growth, as a consequence of proteasomal inhibition and apoptosis induction. During the 29-day treatment with this compound at $1-2 \mathrm{mg} / \mathrm{kg} / \mathrm{day}$, no toxicity was observed, and mice did not display signs of weight loss, decreased activity, or anorexia. However, these toxicity data are preliminary and warrant further investigation.

Other in vivo experiences have been reported for 2-[(dimethylamino) methyl]phenylgold(III) compounds whose general formula is $\left[\left(\mathrm{CR}^{1}\right) \mathrm{AuX} \mathrm{X}_{2}\right]$. One of these compounds in which X corresponds to SCN was evaluated against murine ADJ/PC6 plasmacytoma; only $24 \%$ of tumor growth was inhibited at a dose of $25 \mathrm{mg} / \mathrm{kg}$ (the maximum tolerated dose). Two other compounds in which $\mathrm{X}$ represents the $\mathrm{O}_{2} \mathrm{CMe}$, acetate group and $\mathrm{X}_{2}$ the $\mathrm{O}_{2} \mathrm{CCH}_{2} \mathrm{CO}_{2}$, malonate group show activity comparable to that displayed by cisplatin in a bladder tumor (HT1376) xenograft. The compound characterized by the acetate group shows some antitumor activity also in an ovarian tumor $(\mathrm{CH} 1)$ model. ${ }^{120}$

\section{Animal Pharmacokinetic Data}

There is little pharmacokinetic data on gold(I) compounds in animals and none currently available for gold(III) complexes.

The pharmacokinetics of MU-Gold, tetrakis (trishydroxymethyl) phosphine gold(I) chloride, active in a series of in vitro and in vivo tumor models, have been studied in normal dogs in anticipation of trials in cancer-bearing dogs. ${ }^{126} \mathrm{MU}-$ Gold $(10 \mathrm{mg} / \mathrm{kg})$ was administered by i.v. injection to three purpose-bred dogs. A two-compartment i.v. bolus model with first-order kinetics, mean elimination half-life of approximately $40 \mathrm{hr}$, and mean volume of distribution of $0.6 \mathrm{~L} / \mathrm{kg}$ was established. Serum gold concentrations ranging from 10 to $50 \mu \mathrm{g} / \mathrm{mL}$ were sustained from 2 to 3 days with no clinically significant toxicities observed.

Gold sodium thiomalate was administered to New Zealand white rabbits by two different routes. A single $2 \mathrm{mg} / \mathrm{kg}$ dose of the drug was administered i.m. and i.v. to four and three animals, respectively. ${ }^{127}$ The blood concentration-time profiles were described by a two-compartment open model with first-order absorption by intramuscular route. Gold was absorbed rapidly with a mean absorption half-life of 9.0 min and a peak concentration of $6.0 \pm 1.0 \mu \mathrm{g} / \mathrm{mL}(n=4)$. Blood concentrations declined in a biphasic manner; the mean $\alpha$ halflives were 0.738 and $1.78 \mathrm{hr}$ for the i.v. and i.m. routes, respectively. The corresponding terminal $(\beta)$ half-lives were 54.1 and $63.0 \mathrm{hr}$. The estimated volume of the central compartment $(70-93 \mathrm{~mL} / \mathrm{kg})$ agreed closely with the rabbit blood volume. The mean $( \pm \mathrm{SD})$ extent of the dose absorbed following i.m. injection was $68.9 \pm 12.4 \%$.

\section{CLINICAL INVESTIGATIONS}

To date, gold compounds have not been formally investigated as anticancer drugs in the clinic and no published clinical data are available (PubMed, American Society of Clinical Oncology-ASCO Proceedings, American Association of Cancer Research-AACR Proceedings, reviewed in December 2008). The Mayo Clinic web site (http://clinicaltrials.mayo.edu) reports an ongoing phase I study to evaluate the side effects and the best dose of gold sodium thiomalate administered to patients with NSCLC as well as the effect of this compound on $\mathrm{PKCl}$ expression. 


\section{CONCLUDING REMARKS}

Gold compounds are undoubtedly an interesting class of metal compounds, which have great potential as cytotoxic and anticancer agents. A variety of structurally different gold compounds have been prepared and characterized during the last two decades with unique chemistry at the gold center and pronounced reactivity with a variety of biomolecules. There are evident differences between gold(I) and gold(III) compounds, both in terms of chemistry and biological activity. Their biological properties appear to be critically governed by the coordination environment of the metal center. Extensive data are available on the in vitro cytotoxic activity of several gold compounds and their pronounced growth inhibition in a variety of cell lines. Biochemical and cellular studies indicate a large variety of molecular mechanisms for the numerous cytotoxic gold compounds that are presently under investigation. Some major molecular and cellular targets have been identified. Nevertheless, only a few in vivo studies are available on these compounds at present. It is evident that more extensive in vivo investigations are warranted for gold compounds to assess their possible efficacy as anticancer agents more thoroughly.

\section{REFERENCES}

1. Messori L, Marcon G. Gold complexes in the treatment of rheumatoid arthritis. Met Ions Biol Syst 2004;41279:279-304.

2. Shaw CF III. Gold-based therapeutic agents. Chem Rev 1999;99:2589-2600.

3. Kelland L. The resurgence of platinum-based cancer chemotherapy. Nat Rev Cancer 2007;7: 573-584.

4. Tiekink ER. Gold derivatives for the treatment of cancer. Crit Rev Oncol Hematol 2002;42: 225-248.

5. Rackham O, Nichols SJ, Leedman PJ, Berners-Price SJ, Filipovska A. A gold(I) phosphine complex selectively induces apoptosis in breast cancer cells: Implications for anticancer therapeutics targeted to mitochondria. Biochem Pharmacol 2007;74:992-1002.

6. Gabbiani C, Casini A, Messori L. Gold(III) compounds as anticancer drugs. Gold Bull 2007;40:73-81.

7. Barnard PJ, Berners-Price SJ. Targeting the mitochondrial cell death pathway with gold compounds. Coord Chem Rev 2007;251:1889-1902.

8. Gabbiani C, Casini A, Messori L, Guerri A, Cinellu MA, Minghetti G, Corsini M, Rosani C, Zanello P, Arca M. Structural characterization, solution studies, and DFT calculations on a series of binuclear gold(III) oxo complexes: Relationships to biological properties. Inorg Chem 2008;47:2368-2379.

9. Casini A, Hartinger C, Gabbiani C, Mini E, Dyson PJ, Keppler BK, Messori L. Gold(III) compounds as anticancer agents: Relevance of gold-protein interactions for their mechanism of action. J Inorg Biochem 2008;102:564-575.

10. Shaw CF III. The protein chemistry of antiarthritic gold(I) thiolates and related complexes. Comments Inorg Chem 1989;8:233-267.

11. Grahmann A, Schmidbaur H. In: Abel EW, Stone FGA, Wilkinson G, editors. Comprehensive organometallic chemistry 2. A review of the literature 1982-1994, Vol. 3. Oxford: Pergamon Press; 1995. p 1.

12. Shaw CF III. Chrysotherapy: Gold-drug metabolism and immunochemistry. Top Biol Inorg Chem 1999;2:187.

13. Hernández Méndez J, Sánchez Pérez A, Delgado Zamarreño M. Electrochemical behavior and polarographic determination of auranofin. J Pharm Sci 1989;78:589-591. 
14. Mohamed AA, Bruce AE, Bruce MR. Cyclic voltammetry of auranofin. Met Based Drugs 1999;6:233-238.

15. Messori L, Abbate F, Marcon G, Orioli P, Fontani M, Mini E, Mazzei T, Carotti S, O'Connell T, Zanello P. Gold(III) complexes as potential antitumor agents: Solution chemistry and cytotoxic properties of some selected gold(III) compounds. J Med Chem 2000;43: 3541-3548.

16. Ronconi L, Giovagnini L, Marzano C, Bettì F, Graziani R, Pilloni G, Fregona D. Gold dithiocarbamate derivatives as potential antineoplastic agents: Design, spectroscopic properties, and in vitro antitumor activity. Inorg Chem 2005;44:1867-1881.

17. Che CM, Sun RW, Yu WY, Ko CB, Zhu N, Sun H. Gold(III) porphyrins as a new class of anticancer drugs: Cytotoxicity, DNA binding and induction of apoptosis in human cervix epitheloid cancer cells. Chem Commun (Camb) 2003;14:1718-1719.

18. Wang Y, He QY, Sun RW, Che CM, Chiu JF. Gold(III) porphyrin 1a induced apoptosis by mitochondrial death pathways related to reactive oxygen species. Cancer Res 2005;65: 11553-11564.

19. Messori L, Marcon G, Cinellu MA, Coronnello M, Mini E, Gabbiani C, Orioli P. Solution chemistry and cytotoxic properties of novel organogold(III) compounds. Bioorg Med Chem 2004;12:6039-6043.

20. Coronnello M, Mini E, Caciagli B, Cinellu MA, Bindoli A, Gabbiani C, Messori L. Mechanisms of cytotoxicity of selected organogold(III) compounds. J Med Chem 2005;48:6761-6765.

21. Eisler R. Chrysotherapy: A synoptic review. Inflamm Res 2003;52:487-501.

22. Ho SY, Tiekink ERT. ${ }^{79} \mathrm{Au}$ gold-based metallotherapeutics: Use and potential. In: Gielen M, Tiekink ERT, editors. Metallotherapeutic drugs and metal-based diagnostic agents. The use of metals in medicine. New York: Wiley; 2005. pp 507-527.

23. Stillman MJ, Shaw FC, Suzuki KT, editors. Metallothioneins: Synthesis, structure and properties of metallothioneins. Phytochelatins and metal-thiolate complexes. New York: VCH Publishers; 1992; $\mathrm{p} 443$.

24. Klaassen CD, editor. Metallothionein IV. Basel: Birkhaüser Verlag; 1999. pp 1-645.

25. Choy EH, Gambling L, Best SL, Jenkins RE, Kondeatis E, Vaughan R, Black MM, Sadler PJ, Panayi GS. Nickel contamination of gold salts: Link with gold-induced skin rash. Br J Rheumatol 1997;36:1054-1058.

26. Whitehouse MW, Graham GG. Is local biotransformation the key to understanding the pharmacological activity of salicylates and gold drugs? Inflamm Res 1996;45:579-582.

27. Coffer MT, Shaw CF III, Eidsness MK, Watkins JW II, Elder RC. Reactions of auranofin and $\mathrm{Et}_{3} \mathrm{PAuCl}$ with bovine serum albumin. Inorg Chem 1986;25:333-339.

28. Razi MT, Otiko G, Sadler PJ. Platinum, gold and other metal chemotherapeutic agents. In: Lippard SJ, editor. ACS symposium series, Vol. 209. Washington, DC: ACS; 1983. $371 \mathrm{p}$.

29. Malik NA, Otiko G, Sadler PJ. Control of intra- and extra-cellular sulphydryl-disulphide balances with gold phosphine drugs: ${ }^{31} \mathrm{P}$ nuclear magnetic resonance studies of human blood. J Inorg Biochem 1980;12:317-322.

30. Ecker DJ, Hempel JC, Sutton BM, Kirsch R, Crooke ST. Reactions of the metallodrug auranofin [(1-thio-beta-D-glucopyranose-2,3,4,6-tetraacetato-S)(triethylphosphine)gold] with biological ligands studied by radioisotope methodology. Inorg Chem 1987;26:3139-3143.

31. Laib JE, Shaw CF. Aurothionein formation from $\mathrm{Zn}$, Cd-thionein and $\mathrm{Et}_{3} \mathrm{PAuCl}$, but not Et $_{3}$ PAuSATg (auranofin). Inorg Chim Acta 1986;123:197-199.

32. Christodoulou J, Sadler PJ, Tucker A. A new structural transition of serum albumin dependent on the state of Cys34. Detection by 1H-NMR spectroscopy. Eur J Biochem 1994;225:363-368.

33. Ni Dhubhghaill OM, Sadler PJ, Tucker A. Drug-induced reactions of bovine serum albumin: ${ }^{1} \mathrm{H}$ NMR studies of gold binding and cysteine release. J Am Chem Soc 1992;114:1118-1120. 
34. Coffer MT, Shaw CF III, Hormann AL, Mirabelli CK, Crooke ST. Thiol competition for $\mathrm{Et}_{3}$ PAuS-albumin: A nonenzymatic mechanism for $\mathrm{Et}_{3} \mathrm{PO}$ formation. $\mathrm{J}$ Inorg Biochem 1987;30:177-187.

35. Roberts JR, Shaw CF III. Inhibition of erythrocyte selenium-glutathione peroxidase by auranofin analogues and metabolites. Biochem Pharmacol 1998;55:1291-1299.

36. Isab AA, Shaw CF III, Locke J. GC-MS and ${ }^{17} \mathrm{O}$ NMR tracer studies of $\mathrm{Et}_{3} \mathrm{PO}$ formation from auranofin and $\mathrm{H}_{2}{ }^{17} \mathrm{O}$ in the presence of bovine serum albumin: An in vitro model for auranofin metabolism. Inorg Chem 1988;27:3406-3409.

37. Intoccia AP, Flanagan TL, Walz DT, Gutzait L, Swagzdis JE, Flagillano J Jr, Hwang BY, Dewey RH, Noguchi N. In: Sutton BM, editor. Bioinorganic Chemistry of Gold Coordination Compounds. Philadelphia, PA: Smith Kline and French Laboratories; 1983. 21p.

38. Cottrill SM, Sharma HL, Dyson DB, Parish RV, McCauliffe CA. The role of the ligand in chrysotherapy: A kinetic study of ${ }^{199} \mathrm{Au}$ - and ${ }^{35} \mathrm{~S}$-labelled myocrisin and auranofin. J Chem Soc Perkin Trans 1989;2:53-58.

39. Shaw CF III, Isab AA, Hoeschele JD, Starich M, Locke J, Schulteis P, Xiao J. Oxidation of the phosphine from the auranofin analogue, triisopropylphosphine(2,3,4,6-tetra-o-acetyl-1-thio-betaD-glucopyranosato-s)gold(I), via a protein-bound phosphonium intermediate. J Am Chem Soc 1994;116:2254-2260.

40. Miles AT, Hawksworth GM, Beattie JH, Rodilla V. Induction, regulation, degradation, and biological significance of mammalian metallothioneins. Crit Rev Biochem Mol Biol 2000; 35:35-70.

41. Laib JE, Shaw CF III, Petering DH, Eidsness MK, Elder RC, Garvey JS. Formation and characterization of aurothioneins: $\mathrm{Au}, \mathrm{Zn}, \mathrm{Cd}-$ thionein, $\mathrm{Au}, \mathrm{Cd}$-thionein, and (thiomalato-Au)chithionein. Biochemistry 1985;24:1977-1986.

42. Graham GG, Kettle AJ. The activation of gold complexes by cyanide produced by polymorphonuclear leukocytes. III. The formation of aurocyanide by myeloperoxidase. Biochem Pharmacol 1998;56:307-312.

43. Goebel C, Kubicka-Muranyi M, Tonn T, Gonzalez J, Gleichmann E. Phagocytes render chemicals immunogenic: Oxidation of gold(I) to the $\mathrm{T}$ cell-sensitizing gold(III) metabolite generated by mononuclear phagocytes. Arch Toxicol 1995;69:450-459.

44. Merchant B. Gold, the noble metal and the paradoxes of its toxicology. Biologicals 1998;26:49-59.

45. Smith WE, Reglinski J, Hoey S, Brown DH, Sturrock RD. Action of sodium gold(I) thiomalate on erythrocyte membrane. Inorg Chem 1990;29:5190-5196.

46. Smith WE, Reglinski J. Gold drugs used in the treatment of rheumatoid arthritis. Perspect Bioinorg Chem 1991;1:183-208.

47. Snyder RM, Mirabelli CK, Crooke ST. Cellular association, intracellular distribution, and efflux of auranofin via sequential ligand exchange reactions. Biochem Pharmacol 1986;35: 923-932.

48. Shaw CF III, Isab AA, Coffer MT, Mirabelli CK. Gold(I) efflux from auranofin-treated red blood cells. Evidence for a glutathione-gold-albumin metabolite. Biochem Pharmacol 1990;40: 1227-1234.

49. Mirabelli CK, Sung CM, Zimmerman JP, Hill DT, Mong S, Crooke ST. Interactions of gold coordination complexes with DNA. Biochem Pharmacol 1986;35:1427-1433.

50. Marzano C, Gandin V, Folda A, Scutari G, Bindoli A, Rigobello MP. Inhibition of thioredoxin reductase by auranofin induces apoptosis in cisplatin-resistant human ovarian cancer cells. Free Radic Biol Med 2007;42:872-881.

51. Crooke ST, Mirabelli CK. Molecular mechanisms of action of auranofin and other gold complexes as related to their biologic activities. Am J Med 1983;75:109-113.

52. Novelli F, Recine M, Sparatore F, Juliano C. Gold(I) complexes as antimicrobial agents. Farmaco 1999;54:232-236. 
53. Marcon G, Carotti S, Coronnello M, Messori L, Mini E, Orioli P, Mazzei T, Cinellu MA, Minghetti G. Gold(III) complexes with bipyridyl ligands: Solution chemistry, cytotoxicity, and DNA binding properties. J Med Chem 2002;45:1672-1677.

54. Messori L, Orioli P, Tempi C, Marcon G. Interactions of selected gold(III) complexes with calf thymus DNA. Biochem Biophys Res Commun 2001;281:352-360.

55. Casini A, Cinellu MA, Minghetti G, Gabbiani C, Coronnello M, Mini E, Messori L. Structural and solution chemistry, antiproliferative effects, and DNA and protein binding properties of a series of dinuclear gold(III) compounds with bipyridyl ligands. J Med Chem 2006;49:5524-5531.

56. Carotti S, Marcon G, Marussich M, Mazzei T, Messori L, Mini E, Orioli P. Cytotoxicity and DNA binding properties of a chloro glycylhistidinate gold(III) complex (GHAu). Chem Biol Interact 2000;125:29-38.

57. Messori L, Marcon G, Innocenti A, Gallori E, Franchi M, Orioli P. Molecular recognition of metal complexes by DNA: A comparative study of the interactions of the parent complexes [PtCl(TERPY)]Cl and [AuCl(TERPY)]Cl 2 with double stranded DNA. Bioinorg Chem Appl 2005;3:239-253.

58. Shi P, Jiang Q, Zhao Y, Zhang Y, Lin J, Lin L, Ding J, Guo Z. DNA binding properties of novel cytotoxic gold(III) complexes of terpyridine ligands: The impact of steric and electrostatic effects. J Biol Inorg Chem 2006;11:745-752.

59. Ronconi L, Marzano C, Zanello P, Corsini M, Miolo G, Maccà C, Trevisan A, Fregona D. Gold(III) dithiocarbamate derivatives for the treatment of cancer: Solution chemistry, DNA binding, and hemolytic properties. J Med Chem 2006;49:1648-1657.

60. Wang Y, He QY, Sun RW, Che CM, Chiu JF. Cellular pharmacological properties of gold(III) porphyrin 1a, a potential anticancer drug lead. Eur J Pharmacol 2007;554:113-122.

61. Marcon G, Messori L, Orioli P, Cinellu MA, Minghetti G. Reactions of gold(III) complexes with serum albumin. Eur J Biochem 2003;270:4655-4661.

62. Rigobello MP, Scutari G, Boscolo R, Bindoli A. Induction of mitochondrial permeability transition by auranofin, a gold(I)-phosphine derivative. Br J Pharmacol 2002;136:1162-1168.

63. Rigobello MP, Messori L, Marcon G, Agostina Cinellu M, Bragadin M, Folda A, Scutari G, Bindoli A. Gold complexes inhibit mitochondrial thioredoxin reductase: Consequences on mitochondrial functions. J Inorg Biochem 2004;98:1634-1641.

64. Arnér ES, Holmgren A. The thioredoxin system in cancer. Semin Cancer Biol 2006;6:420-426.

65. Holmgren A. Thioredoxin. Annu Rev Biochem 1985;54:237-271.

66. Qin J, Clore GM, Kennedy WP, Hutch JR, Gronenborn AM. Solution structure of human thioredoxin in a mixed disulfide intermediate complex with its target peptide from the transcription factor NF-кB. Structure 1994;3:289-297.

67. Abate C, Patel L, Rauscher FJ 3rd, Curran T. Redox regulation of fos and jun DNA-binding activity in vitro. Science 1990;249:1157-1161.

68. Ueno M, Masutani H, Arai RJ, Yamauchi A, Hirota K, Sakai T, Inamoto T, Yamaoka Y, Yodoi J, Nikaido T. Thioredoxin-dependent redox regulation of p53-mediated p21 activation. J Biol Chem 1999;274:35809-35815.

69. Engman L, McNaughton M, Gajewska M, Kumar S, Birmingham A, Powis G. Thioredoxin reductase and cancer cell growth inhibition by organogold(III) compounds. Anticancer Drugs 2006;17:539-544.

70. Nguyen P, Awwad RT, Smart DD, Spitz DR, Gius D. Thioredoxin reductase as a novel molecular target for cancer therapy. Cancer Lett 2006;236:164-174.

71. Grogan TM, Fenoglio-Prieser C, Zeheb R, Bellamy W, Frutiger Y, Vela E, Stemmerman G, Macdonald J, Richter L, Gallegos A, Powis G. Thioredoxin, a putative oncogene product, is overexpressed in gastric carcinoma and associated with increased proliferation and increased cell survival. Hum Pathol 2000;31:475-481.

72. Raffel J, Bhattacharyya AK, Gallegos A, Cui H, Einspahr JG, Alberts DS, Powis G. Increased expression of thioredoxin-1 in human colorectal cancer is associated with decreased patient survival. J Lab Clin Med 2002;142:46-51. 
73. Gromer S, Arscott LD, Williams CH Jr, Schirmer RH, Becker K. Human placenta thioredoxin reductase. Isolation of the selenoenzyme, steady state kinetics, and inhibition by therapeutic gold compounds. J Biol Chem 1998;273:20096-20101.

74. Omata Y, Folan M, Shaw M, Messer RL, Lockwood PE, Hobbs D, Bouillaguet S, Sano H, Lewis JB, Wataha JC. Sublethal concentrations of diverse gold compounds inhibit mammalian cytosolic thioredoxin reductase (TrxR1). Toxicol In Vitro 2006;20:882-890.

75. McKeage MJ, Maharaj L, Berners-Price SJ. Mechanisms of cytotoxicity and antitumor activity of gold(I) phosphine complexes: The possible role of mitochondria. Coord Chem Rev 2002;232: $127-135$.

76. Hickey JL, Ruhayel RA, Barnard PJ, Baker MV, Berners-Price SJ, Filipovska A. Mitochondriatargeted chemotherapeutics: The rational design of gold(I) $N$-heterocyclic carbene complexes that are selectively toxic to cancer cells and target protein selenols in preference to thiols. J Am Chem Soc 2008;130:12570-12571.

77. Cinellu MA, Zucca A, Stoccoro S, Minghetti G, Manassero M, Sansoni M. Synthesis and characterization of gold(III) adducts and cyclometallated derivatives with 2-substituted pyridines. Crystal structure of $\left[\mathrm{Au}\left\{\mathrm{NC}_{5} \mathrm{H}_{4} \quad\left(\mathrm{CMe}_{2} \mathrm{C}_{6} \mathrm{H}_{4}\right)-2\right\} \mathrm{Cl}_{2}\right]$. J Chem Soc Dalton Trans 1995;(17):2865-2872. DOI: 10.1039/DT9950002865

78. Cinellu MA, Zucca A, Stoccoro S, Minghetti G, Manassero M, Sansoni M. Synthesis and characterization of gold(III) adducts and cyclometallated derivatives with 6-benzyl- and 6-alkyl2,2'-bipyridines. J Chem Soc Dalton Trans 1996;(22):4217-4225. DOI: 10.1039/DT9960004217

79. Cinellu MA, Minghetti G, Pinna MV, Stoccoro S, Zucca A, Manassero M. Replacement of the chloride ligand in $[\mathrm{Au}(\mathrm{C}, N, N) \mathrm{Cl}]\left[\mathrm{PF}_{6}\right]$ cyclometallated complexes by $\mathrm{C}, \mathrm{N}, \mathrm{O}$ and $\mathrm{S}$ donor anionic ligands. J Chem Soc Dalton Trans 1999;(16):2823-2832. DOI: 10.1039/a903925b

80. Cinellu MA, Minghetti G, Pinna MV, Stoccoro S, Zucca A, Manassero M. Synthesis and characterization of mononuclear amidogold(III) complexes-Crystal structure of $\left[\mathrm{Au}\left(\mathrm{N}_{2} \mathrm{C}_{10} \mathrm{H}_{7}\left(\mathrm{CMe}_{2} \mathrm{C}_{6} \mathrm{H}_{4}\right)-6\right)\left(\mathrm{NHC}_{6} \mathrm{H}_{3} \mathrm{Me}_{2} 2,6\right)\right]\left[\mathrm{PF}_{6}\right]$-Oxidation of 4-methylaniline to azotoluene. Eur J Inorg Chem 2003;12:2304-2310.

81. Saggioro D, Rigobello MP, Paloschi L, Folda A, Moggach SA, Parsons S, Ronconi L, Fregona D, Bindoli A. Gold(III)-dithiocarbamate complexes induce cancer cell death triggered by thioredoxin redox system inhibition and activation of ERK pathway. Chem Biol 2007;14:1128-1139.

82. Park SJ, Kim IS. The role of p38 MAPK activation in auranofin-induced apoptosis of human promyelocytic leukaemia HL-60 cells. Br J Pharmacol 2005;146:506-513.

83. Jellicoe MM, Nichols SJ, Callus BA, Baker MV, Barnard PJ, Berners-Price SJ, Whelan J, Yeoh GC, Filipovska A. Bioenergetic differences selectively sensitize tumorigenic liver progenitor cells to a new gold(I) compound. Carcinogenesis 2008;29:1124-1133.

84. Wang Y, He QY, Che CM, Chiu JF. Proteomic characterization of the cytotoxic mechanism of gold(III) porphyrin 1a, a potential anticancer drug. Proteomics 2006;6:131-142.

85. Wang Y, He QY, Che CM, Tsao SW, Sun RW, Chiu JF. Modulation of gold(III) porphyrin 1ainduced apoptosis by mitogen-activated protein kinase signaling pathways. Biochem Pharmacol 2008;75:1282-1291.

86. Aldinucci D, Lorenzon D, Stefani L, Giovagnini L, Colombatti A, Fregona D. Antiproliferative and apoptotic effects of two new gold(III) methylsarcosinedithiocarbamate derivatives on human acute myeloid leukemia cells in vitro. Anticancer Drugs 2007;18:323-332.

87. Mani A, Gelmann EP. The ubiquitin-proteasome pathway and its role in cancer. J Clin Oncol 2005;23:4776-4789.

88. Milacic V, Chen D, Ronconi L, Landis-Piwowar KR, Fregona D, Dou QP. A novel anticancer gold(III) dithiocarbamate compound inhibits the activity of a purified $20 \mathrm{~S}$ proteasome and $26 \mathrm{~S}$ proteasome in human breast cancer cell cultures and xenografts. Cancer Res 2006;66:10478-10486.

89. Wodarz A, Näthke I. Cell polarity in development and cancer. Nat Cell Biol 2007;9:1016-1024.

90. Fields AP, Gustafson WC. Protein kinase C in disease: Cancer. Methods Mol Biol 2003;233: 519-537. 
91. Dorn GW 2nd, Souroujon MC, Liron T, Chen CH, Gray MO, Zhou HZ, Csukai M, Wu G, Lorenz JN, Mochly-Rosen D. Sustained in vivo cardiac protection by a rationally designed peptide that causes epsilon protein kinase C translocation. Proc Natl Acad Sci USA 1999;96: 12798-12803.

92. Goekjian PG, Jirousek MR. Protein kinase C inhibitors as novel anticancer drugs. Expert Opin Investig Drugs 2001;10:2117-2140.

93. Fields AP, Regala RP. Protein kinase C1: Human oncogene, prognostic marker and therapeutic target. Pharmacol Res 2007;55:487-497.

94. Nishizuka Y. Protein kinase $\mathrm{C}$ and lipid signaling for sustained cellular responses. FASEB J 1995;9:484-496.

95. Ono Y, Fujii T, Ogita K, Kikkawa U, Igarashi K, Nishizuka Y. Protein kinase C $\zeta$ subspecies from rat brain: Its structure, expression, and properties. Proc Natl Acad Sci USA 1989;86: 3099-3103.

96. Nakanishi H, Brewer KA, Exton JH. Activation of the $\zeta$ isozyme of protein kinase $\mathrm{C}$ by phosphatidylinositol 3,4,5-trisphosphate. J Biol Chem 1993;268:13-16.

97. Le Good JA, Ziegler WH, Parekh DB, Alessi DR, Cohen P, Parker PJ. Protein kinase C isotypes controlled by phosphoinositide 3-kinase through the protein kinase PDK1. Science 1998;281: 2042-2045.

98. Dong LQ, Zhang RB, Langlais P, He H, Clark M, Zhu L, Liu F. Primary structure, tissue distribution, and expression of mouse phosphoinositide-dependent protein kinase-1, a protein kinase that phosphorylates and activates protein kinase C $\zeta$. J Biol Chem 1999;274: $8117-8122$.

99. Moscat J, Diaz-Meco MT. The atypical protein kinase Cs. Functional specificity mediated by specific protein adapters. EMBO Rep 2000;1:399-403.

100. Regala RP, Weems C, Jamieson L, Copland JA, Thompson EA, Fields AP. Atypical protein kinase $\mathrm{Cl}$ plays a critical role in human lung cancer cell growth and tumorigenicity. J Biol Chem 2005;280:31109-31115.

101. Erdogan E, Lamark T, Stallings-Mann M, Jamieson L, Pellecchia M, Thompson EA, Johansen T, Fields AP. Aurothiomalate inhibits transformed growth by targeting the PB1 domain of protein kinase Cr. J Biol Chem 2006;281:28450-28459.

102. Stallings-Mann M, Jamieson L, Regala RP, Weems C, Murray NR, Fields AP. A novel smallmolecule inhibitor of protein kinase $\mathrm{C}$ blocks transformed growth of non-small-cell lung cancer cells. Cancer Res 2006;66:1767-1774.

103. Simon TM, Kunishima DH, Vibert GJ, Lorber A. Cellular antiproliferative action exerted by auranofin. J Rheumatol Suppl 1979;5:91-97.

104. Mirabelli CK, Johnson RK, Hill DT, Faucette LF, Girard GR, Kuo GY, Sung CM, Crooke ST. Correlation of the in vitro cytotoxic and in vivo antitumor activities of gold(I) coordination complexes. J Med Chem 1986;29:218-223.

105. Mirabelli CK, Jensen BD, Mattern MR, Sung CM, Mong SM, Hill DT, Dean SW, Schein PS, Johnson RK, Crooke ST. Cellular pharmacology of mu-[1,2-bis(diphenylphosphino)ethane]bis[(1thio-beta-D-gluco pyranosato-S)gold(I)]: A novel antitumor agent. Anticancer Drug Des 1986;1: 223-234.

106. Sadler PJ, Sue RE. The chemistry of gold drugs. Met Based Drugs 1994;1:107-144.

107. Papathanasiou P, Salem G, Waring P, Willis AC. Synthesis of gold(I), silver(I) and copper(I) complexes containing substituted (2-aminophenyl)phosphines. Molecular structure of [AuI(2$\left.\left.\mathrm{H}_{2} \mathrm{NC}_{6} \mathrm{H}_{4} \mathrm{PPhe}\right)\right]$, [AuI $\left.\left\{( \pm)-2 \mathrm{H}_{2} \mathrm{NC}_{6} \mathrm{H}_{4} \mathrm{PMePh}\right\}\right]$ and $( \pm)-\left[\mathrm{Cu}\left(2-\mathrm{H}_{2} \mathrm{NC}_{6} \mathrm{H}_{4} \mathrm{PPh}_{2}\right)_{2}\right] \mathrm{PF}_{6}$. J Chem Soc Dalton Trans 1997;(19):3435-3443. DOI: 10.1039/a702757e

108. McKeage MJ, Papathanasiou P, Salem G, Sjaarda A, Swiegers GF, Waring P, Wild SB. Antitumor activity of gold(I), silver(I) and copper(I) complexes containing chiral tertiary phosphines. Met Based Drugs 1998;5:217-223. 
109. De Pancorbo MM, Garcia-Orad A, Paz Arizti M, Gutièrrez-Zorrilla JM, Colacio E. In: Collery Ph, Poirier LA, Manfait M, Etienne JC, editors. Metals ions in biology and medicine. Paris: John Libbey Eurotext; 1990. p 385.

110. Garcia-Orad A, Arizti P, Sommer F, Silvestro L, Massiot P, Chevallier P, Gutierrez-Zorrilla JM, Colacio E, Martinez de Pancorbo M, Tapiero H. The (8-thiotheophyllinate) (triphenylphosphine) gold (I), (tTAuP): A new gold complex as an anticancer agent. Biomed Pharmacother 1993;47: 363-370.

111. Arizti MP, Garcia-Orad A, Sommer F, Silvestro L, Massiot P, Chevallier P, Gutiérrez-Zorrilla JM, Colacio E, Martinez de Pancorbo M, Tapiero H. Intracellular accumulation and cytotoxic effect of (8-thiotheophyllinate) (triphenylphosphine) gold(I) in Friend leukemia cells. Anticancer Res 1991;11:625-628.

112. Webster LK, Rainone S, Horn E, Tiekink ER. Anti-tumor activity, in vitro and in vivo, of some triphenylphosphinegold(I) thionucleobases. Met Based Drugs 1996;3:63-66.

113. Crump D, Siasios G, Tiekink ER. A study of the antitumour activity of four triorganophosphinegold(I) thiolates: $\mathrm{R}_{3} \mathrm{PAu}\left(\mathrm{SR}^{\prime}\right), \mathrm{R}=\mathrm{Ph}, \mathrm{Cy}, \mathrm{Et}$; $\mathrm{SR}^{\prime} \mathrm{H}=6$-mercaptopurine and $\mathrm{R}=\mathrm{Et}$; $\mathrm{SR}^{\prime} \mathrm{H}=6$-thioguanine. Met Based Drugs 1999;6:361-368.

114. de Vos D, Clements P, Pyke SM, Smyth DR, Tiekink ER. Characterisation and in vitro cytotoxicity of triorganophosphinegold(I) 2-mercaptobenzoate complexes. Met Based Drugs 1999;6:31-40.

115. Moustatih A, Garnier-Suillerot A. Bifunctional antitumor compounds: Synthesis and characterization of an $\mathrm{Au}(\mathrm{III})$-streptonigrin complex with thiol-modulating properties. J Med Chem 1989;32:1426-1431.

116. Kivekas R, Colacio E, Ruiz J, Lopez-Gonzalez JD, Leon P. Chlorogold(I) and gold(III) complexes of 6-amino-1,3-dimethyl-5-arylazouracil derivatives: IR spectroscopy, growth inhibition of $\mathrm{HeLa}$ cells and X-ray crystal structure of 6-amino-1,3-dimethyl-5phenylazoniumuracil dichloroaurate(I) sesquihydrate. Inorg Chim Acta 1989;159:103-110.

117. Cossu F, Matovic Z, Radanovic D, Ponticelli G. Cytotoxic activity of some gold(III) complexes. Farmaco 1994;49:301-302.

118. Calamai P, Carotti S, Guerri A, Mazzei T, Messori L, Mini E, Orioli P, Speroni GP. Cytotoxic effects of gold(III) complexes on established human tumor cell lines sensitive and resistant to cisplatin. Anticancer Drug Des 1998;13:67-80.

119. Parish RV, Howe BP, Wright JP, Mack J, Pritchard RG, Buckley RG, Elsome AM, Fricker SP. Chemical and biological studies of dichloro(2-((dimethylamino)methyl)phenyl)gold(III). Inorg Chem 1996;35:1659-1666.

120. Buckley RG, Elsome AM, Fricker SP, Henderson GR, Theobald BR, Parish RV, Howe BP, Kelland LR. Antitumor properties of some 2-[(dimethylamino)methyl]phenylgold(III) complexes. J Med Chem 1996;39:5208-5214.

121. Mirabelli CK, Johnson RK, Sung CM, Faucette L, Muirhead K, Crooke ST. Evaluation of the in vivo antitumor activity and in vitro cytotoxic properties of auranofin, a coordinated gold compound, in murine tumor models. Cancer Res 1985;45:32-39.

122. Simon TM, Kunishima DH, Vibert GJ, Lorber A. Screening trial with the coordinated gold compound auranofin using mouse lymphocyte leukemia P388. Cancer Res 1981;41:94-97.

123. Giraldi T, Sava G, Perissin L, Zorzet S. Primary tumor growth and formation of spontaneous lung metastases in mice bearing Lewis carcinoma treated with proteinase inhibitors. Anticancer Res 1984;4:221-224.

124. Kamei H, Koide T, Kojima T, Hashimoto Y, Hasegawa M. Effect of gold on survival of tumorbearing mice. Cancer Biother Radiopharm 1998;13:403-406.

125. Lum CT, Yang ZF, Li HY, Wai-Yin Sun R, Fan ST, Poon RT, Lin MC, Che CM, Kung HF. Gold(III) compound is a novel chemocytotoxic agent for hepatocellular carcinoma. Int $\mathrm{J}$ Cancer 2006;118:1527-1538. 
126. Higginbotham ML, Henry CJ, Katti KV, Casteel SW, Dowling PM, Pillarsetty N. Preclinical tolerance and pharmacokinetic assessment of MU-Gold, a novel chemotherapeutic agent, in laboratory dogs. Vet Ther 2003;4:76-82.

127. Melethil S, Schoepp D. Pharmacokinetics of gold sodium thiomalate in rabbits. Pharm Res 1987;4:332-336.

Stefania Nobili is a Research Fellow at the Department of Pharmacology, University of Florence, Italy. She received her Pharm.D. degree from the University of Rome "La Sapienza," Italy, in 1989, her specialization in Applied Pharmacology from the University of Florence in 1997, and her Ph.D. in Chemotherapy from the University of Milan, Italy, in 2001. At present she works in the Laboratory of Anticancer Chemotherapy, Department of Pharmacology, University of Florence directed by Prof. Enrico Mini. Her research interests focus on preclinical and clinical anticancer drug pharmacology and in particular on mechanisms of drug resistance, with emphasis on drugs used in the treatment of gastrointestinal neoplasms.

Enrico Mini is a Professor of Medical Oncology at the University of Florence and an Attending Physician at the Chemotherapy Unit of the University Hospital of Florence, Italy. He received his M.D. degree from the University of Florence, Italy, in 1977 and his Ph.D. in Pharmacology at the University of Florence in 1988. He was previously a Leukemia Society of America Special Fellow at the Departments of Pharmacology and Medicine of the Yale University School of Medicine, New Haven, CT, and Lady Tata Memorial Trust Awardee at the Department of Pharmacology of University of Florence. He was a Lecturer in Pharmacology at the Universities of Siena and Ferrara. From 1992 to 2001 he was an Associate Professor of Pharmacology and from 2001 to 2008 a Professor of Pharmacology at the University of Florence. He currently acts as the Head of the Laboratory of Anticancer Chemotherapy at the Department of Pharmacology of the University of Florence. Since 1998 he is a Member of the Steering Committee of the European Organization for Research and Treatment of Cancer (EORTC), Pan-European Trials in Adjuvant Colon Cancer (PETACC). From 2007 he is the Chairman of the Cancer Section of the International Society of Chemotherapy. His main research interests include the pharmacology of antimetabolite drugs, anticancer drug resistance, cancer pharmacogenomics, and controlled clinical trials in gastrointestinal oncology. He is the author of more than 100 publications on peer-reviewed journals.

Ida Landini is a Research Fellow at the Department of Pharmacology, University of Florence, Italy. She received her B.Sci. degree from the University of Florence in 1998, her Ph.D. in Molecular Pharmacology and Toxicology from the University of Siena in 2003. At present she works in the Laboratory of Anticancer Chemotherapy, Department of Pharmacology, University of Florence directed by Prof. Enrico Mini. Her main research interest is the study of cytotoxic activity of new potential drugs for cancer treatment.

Chiara Gabbiani received her degree in 2003 and her Ph.D. in 2008 in Chemical Sciences from the University of Florence. Her Ph.D. research project concerned the studies on proteins as possible targets for antitumor metal complexes. Another important subject of her studies is the investigation of gold(III) complexes as anticancer agents. She is presently holding a postdoc position in Prof. Messori's research group in Florence to continue the studies on these topics. 
Angela Casini received her B.Sc. in Chemistry from the University of Florence in 1998 and the Ph.D. in Chemical Sciences from the same University in 2004. Her Ph.D. research project concerned the development of novel metalloenzyme inhibitors with particular focus on carbonic anhydrase inhibitors. She is presently holding a position as a Senior Scientist at the Ecole Polytechnique Fédérale de Lausanne, Switzerland, funded by the Swiss National Science Foundation (SNSF) to perform studies on the interactions of anticancer metal complexes with biomolecules with particular attention to proteins as possible targets for the pharmacological activity of this type of drugs.

Luigi Messori received Ph.D. in Chemical Sciences in 1987. He is an Associate Professor of General and Inorganic Chemistry and a member of the Department of Chemistry, University of Florence. His main research interests are in the field of bioinorganic chemistry. In the first phase he has been involved in the study of the solution behavior of metalloproteins, with emphasis on metal carrier proteins. Later on, his research interests moved to consider the role of metal ions in medicine. In particular, he has directed his attention toward antitumour metal complexes (mainly ruthenium(III) and gold(III) complexes) and to their interactions with nucleic acids and proteins. Recent achievements of his scientific activity are a number of studies on anticancer gold(III) complexes and a few biophysical studies concerning the adducts of platinum drugs with some proteins. He has been the Coordinator of a COST D20 WG focusing on the interactions of anticancer metallodrugs with plasma proteins. He has given several invited lectures in Italy and abroad on the above topics. He is the author of more than 130 papers, published in international scientific journals. 